\title{
Polska a sprawa rumuńsko-sowieckiego paktu o nieagresji w latach 1931-1932
}

Zarys treści: Pozostająca od 1921 r. w aliansie z Polską Rumunia od pojawienia się w 1931 r. inicjatywy zawarcia paktu o nieagresji z ZSRR nie widziała dla siebie w związku z nim większych korzyści. Politycy bukareszteńscy niepokoili się, iż rozmowy o pakcie wyciągną na światło dzienne sprawę Besarabii, której przynależność do Rumunii nie miała sankcji międzynarodowej ani uznania Związku Sowieckiego. Obawiali się również, iż podpisanie paktu w konsekwencji przyniesie nawiązanie dyplomatycznych stosunków rumuńsko-sowieckich i otworzy tym samym Królestwo Rumunii na wpływy komunistyczne, co przy ostrych problemach społecznych, będących jego udziałem, mogło poważnie zdestabilizować sytuację wewnętrzną. Dyplomacja polska usiłowała doprowadzić do zbliżenia stanowisk obu państw. Jednak bezkompromisowe wymagania stawiane paktowi przez wpływowego dyplomatę rumuńskiego Nicolae Titulescu oraz krytyczne nastawienie do tego układu premiera Francji André Tardieu, spowodowały całkowity zastój w tej sprawie.

Outline of content: Ever since the emergence in 1931 of the idea of signing a non-aggression pact with the USSR, the Romanians, bound since 1921 by an alliance with Poland, remained sceptical about their own benefits from such an agreement. The politicians in Bucharest feared that the negotiations would evoke the question of Bessarabia, a region which underwent a controversial unification process with Romania that remained unapproved by the international community and unrecognised by the USSR. They also worried that the pact would result in the establishment of diplomatic relations between the two countries, thus opening the Kingdom of Romania to communist influence, which, in the light of the acute social troubles it raises, could strongly destabilise the internal situation in the country. Polish diplomacy attempted to bring both sides closer, yet the uncompromised demands made by the influential Romanian diplomat Nicolae Titulescu, as well as the critical attitude of French Prime Minister André Tardieu towards the whole initiative resulted in a total standstill.

Słowa kluczowe: Polska, Rumunia, Związek Sowiecki, rumuńsko-sowiecki pakt o nieagresji 19311932, Nicolae Titulescu, stosunki polsko-rumuńskie przed II wojną światową 
Keywors: Poland, Romania, Soviet Union, Romania-Soviet pact of non-aggression 1931-1932, Nicolae Titulescu, Polish-Romania relations in interwar period

Na początku lat 30. w europejskim systemie stosunków międzynarodowych zaczęły się rysować nowe trendy. W Niemczech, które po Locarno wraz z Francją i Wielką Brytanią miały współtworzyć zachodnioeuropejski system bezpieczeństwa, w miarę uwalniania się z pęt traktatu wersalskiego zaczęły narastać tendencje rewizjonistyczne skierowane na Wschód Europy. Kryzys gospodarczy, który ogarnął Niemcy w 1929 r. zwiększył popularność ugrupowań ekstremistycznych na czele z Narodowosocjalistyczną Niemiecką Partią Robotniczą głoszącą hasła odwetowe, szowinistyczne i antykomunistyczne. Po wyborach wrześniowych 1930 r. partia ta wprowadziła do Reichstagu 107 swoich przedstawicieli (wcześniej posiadała 12 mandatów) ${ }^{1}$.

Nowe elementy w sytuacji politycznej Republiki Weimarskiej wzbudzały zaniepokojenie Związku Sowieckiego, który nie życzył sobie zbyt ścisłej współpracy Berlina, Paryża i Londynu, gdyż stanowiła ona niebezpieczeństwo dla symbolizowanego przez układ w Rapallo współdziałania niemiecko-sowieckiego, grożąc $\mathrm{w}$ opinii Kremla powstaniem frontu antysowieckiego. Jeszcze większe zagrożenie dla tego współdziałania mogło stanowić dojście do władzy w Rzeszy antysowiecko i antykomunistycznie nastawionego wodza NSDAP - Adolfa Hitlera. Przed polityką radziecką rysowała się zatem perspektywa izolacji, tym większej, że na Dalekim Wschodzie coraz agresywniej poczynała sobie Japonia, godząc w interesy ZSRR ${ }^{2}$.

Alternatywą dla Moskwy w wypadku załamania się współpracy z Berlinem w zasadzie pozostawała tylko Francja, która ze względu na sytuację w Niemczech także była zainteresowana kooperacją z ZSRR, tym bardziej iż jej dotychczasowe działania podejmowane po Locarno wraz z Wielką Brytanią doprowadzenia do modus vivendi z Rzeszą rokowały coraz mniejsze szanse powodzenia ${ }^{3}$.

Pojawienie się oznak świadczących o zmianach rysujących się w europejskim porządku politycznym było z punktu widzenia Polski zjawiskiem korzystnym. Osłabieniu bowiem ulegała lokarneńska polityka kooperacji mocarstw zachodnich z Niemcami skutkująca m.in. wycofywaniem się Paryża ze zobowiązań sojuszniczych wobec Warszawy; postępował również rozkład współpracy niemiecko-sowieckiej, wykluczającej dotąd możliwość porozumienia Polski zarówno ze Związkiem Radzieckim, jak i z Niemcami. W tych okolicznościach z uwagą przyglądano się

1 M. J. Zacharias, Polska wobec zmian w układzie sił politycznych w Europie w latach 1932-1936, Wrocław-Łódź 1981, s. 16-17; S. Sierpowski, Przemiany w polityce międzynarodowej w latach wielkiego kryzysu gospodarczego 1929-1933/35, [w:] Niemcy w polityce międzynarodowej 1919-1939, t. 2, Lata wielkiego kryzysu gospodarczego, red. S. Sierpowski, Poznań 1992, s. 17; T. Schramm, Niemcy w polityce Francji, [w:] Niemcy w polityce..., s. 231.

2 A. Skrzypek, Nie spetniony sojusz? Stosunki sowiecko-niemieckie 1917-1941, Warszawa 1992; idem, Niemcy w polityce ZSRR 1929-1935, [w:] Niemcy w polityce..., s. 183; M. J. Zacharias, op. cit., s. 17-18.

3 M. Leczyk, We francusko-polsko-rosyjskim trójkacie (1922-1934), „Dzieje Najnowsze”, 1999, nr 3, s. 73; S. Gregorowicz, Polsko-radzieckie stosunki polityczne w latach 1932-1935, Wrocław-Łódź 1982, s. 34-35; M. Wołos, Francja-ZSRR. Stosunki polityczne w latach 1924-1932, Toruń 2004, passim. 
w Warszawie ociepleniu stosunków francusko-sowieckich, do którego doszło na tle napięć między Paryżem i Berlinem związanych z godzącym w ład wersalski niemiecko-austriackim protokołem o unii celnej ${ }^{4}$.

W kwietniu 1931 r. Francja wystąpiła z inicjatywą wobec ZSRR zawarcia paktu o nieagresji oraz tymczasowego układu handlowego. Ambasador francuski w Warszawie, Jules Laroche, poinformował o tym przedsięwzięciu polskie MSZ, które zdopingowane tym faktem zdecydowało o wznowieniu, przerwanych w 1927 r., rokowań z Moskwą w sprawie paktu o nieagresji. Podobnie jak wtedy, a także przy okazji protokołu Litwinowa, zamierzano koordynować te rozmowy z negocjacjami dotyczącymi podobnego paktu, prowadzonymi ze Związkiem Radzieckim przez jego innych zachodnich sąsiadów, a więc Finlandię, Estonię, Łotwę i Rumunię. Celem dyplomacji RP stało się stworzenie wspólnego bloku wobec Moskwy, podnoszącego stan bezpieczeństwa w tej części Europy. Realizacji planów Warszawy sprzyjało zastrzeżenie Aristide’a Brianda - ministra spraw zagranicznych Francji, poczynione 22 maja 1931 r. wobec Maksima Litwinowa - ludowego komisarza spraw zagranicznych Związku Radzieckiego, uzależniające podpisanie francusko-sowieckiego paktu o nieagresji od uprzedniego sfinalizowania przez Moskwę podobnych układów z Polską i Rumunią .

Dla stworzenia wspólnej płaszczyzny negocjacji z Moskwą, polskie MSZ przesłało do resortów spraw zagranicznych państw bałtyckich i Rumunii swój projekt paktu o nieagresji z prośbą o wyrażenie opinii. 7 maja 1931 r. poseł polski w Bukareszcie Jan Szembek przekazał ten dokument ministrowi spraw zagranicznych Rumunii, Dimitrie Ghice. Na jego treść składała się preambuła, siedem artykułów i protokół końcowy. W części wstępnej Polska i Związek Sowiecki w zamiarze umocnienia położenia w Europie Wschodniej drogą porozumienia politycznego, uznawszy pokój ryski za podstawę wzajemnych relacji, a pokojowe rozstrzyganie konfliktów za najpewniejszy środek osiągnięcia celu, postanowiły zawrzeć traktat będący rozwinięciem i dopełnieniem paktu paryskiego z 27 sierpnia i protokołu moskiewskiego

4 S. Gregorowicz, op. cit., s. 36-39; H. Bułhak, Polska-Francja. Z dziejów sojuszu 1922-1939, cz. I (1922-1932), Warszawa 1993, s. 281; P. S. Wandycz, The Twilight of French Eastern Alliances 1926-1936: French-Czechoslovak-Polish Relations from Locarno to the Remilitarization of the Rhineland, Princeton 1988, s. 163 i n.; F. Dessberg, La Roumanie et la Pologne dans la politique soviétique de la France. La difficulté détablir un «front uni» (1924-1935), „Revue Historique des Armées”, 2006, nr 3 (244), s. 69.

5 Telegram okólny A. Zaleskiego z 2 V 1931, nr 26. Hoover Institution Archives (dalej: HIA). Polska. Poselstwo Rumunia (dalej: Rumunia). Księga szyfrów (dalej: Ks. szyf.) nr 5, pudło (dalej: p.) 2, folder (dalej: f.) 2; telegram Becka do poselstwa w Bukareszcie z 6 V 1931, nr 39, ibidem; telegram okólny J. Becka z 7 V 1931, nr 40, ibidem; J. Laroche, Polska lat 1926-1935. Wspomnienia ambasadora francuskiego, przekład i opracowanie S. Zabiełło, Warszawa 1966, s. 107; A. Ševâkov, Sovetsko-rumynskie otnošeniâ i problema evropejskoj bezopasnosti, 1932-1939, Moskva 1977, s. 19; M. Leczyk, Polityka II Rzeczypospolitej wobec ZSRR w latach 1925-1934. Studium z historii dyplomacji, Warszawa 1976, s. 70 i n.; S. Łopatniuk, Polsko-radzieckie rokowania w sprawie zawarcia paktu o nieagresji (1925-1932), „Z dziejów stosunków polsko-radzieckich” (dalej: ZDSPR), 1965, t. I, s. 69 i n., M. Wołos, op. cit., s. 488-499; A. Skrzypek, Polsko-radziecki pakt o nieagresji z 1932 r., ZDSPR 1976, t. XIII, s. 17-18. 
z 9 lutego 1929 roku. W artykule I sygnatariusze opowiadając się za odrzuceniem wojny jako narzędzia polityki narodowej we wzajemnych stosunkach, zobowiązywali się powstrzymywać przed wszelkimi agresywnymi działaniami bądź napaścią na siebie. Za sprzeczne z tym zobowiązaniem traktowano wszelki akt gwałtu lub groźbę gwałtu godzące w całość i integralność terytorialną lub niezależność polityczną drugiej strony, nawet jeśli zostałyby one popełnione bez wypowiedzenia wojny i z uniknięciem wszelkich jej możliwych skutków. Artykuł II zobowiązywał sygnatariuszy do niepomagania i niepopierania państwa trzeciego bądź grupy państw trzecich, jeśli dokonałyby one agresji na jednego z partnerów. Kolejny artykuł zastrzegał, iż obowiązki Polski jako członka Ligi Narodów i partycypanta aliansów obronnych nie mogą być ograniczane i modyfikowane przez zobowiązania określone w artykułach I i II. W artykule IV obie strony zgadzały się na rozstrzyganie wszelkich konfliktów wyłącznie drogą pokojową w trybie dyplomatycznym bądź procedury zawartej w konwencji koncyliacyjno-arbitrażowej, mającej stanowić integralną część paktu. Artykuł V zapowiadał zaproszenie państw, które zawarły protokół moskiewski do podpisania analogicznych paktów z ZSRR. W artykule VI przewidywano wejście w życie paktu po 30 dniach od zawiadomienia przez jedną ze stron o ratyfikacji podobnych paktów zawartych przez Związek Sowiecki z Estonią, Finlandią, Łotwą i Rumunią. Artykuł ostatni zawierał stwierdzenie o 3-letnim okresie obowiązywania traktatu i przewidywał jego ewentualną milczącą prolongatę, jeśli nie zostanie on wypowiedziany przez jednego z sygnatariuszy trzy miesiące przed końcem obowiązywania.

W protokole podpisania obie strony stwierdzały, iż jego wymówienie bądź przedłużenie nie ugodzi w ich zobowiązania wypływające z paktu paryskiego ${ }^{6}$.

Przy okazji przekazania projektu Szembek w imieniu władz polskich wystąpił z pytaniem o zamiary Rumunów w kwestii podpisania z ZSRR analogicznego paktu, ich opinię co do jego treści oraz stanowisko w sprawie pośrednictwa Polski w ewentualnych negocjacjach. Minister Ghica, będący wyrazicielem poglądów dużej części rumuńskiego establishmentu, obawiał się układu z Moskwą, nawet jeśli jego konsekwencją byłoby uznanie suwerenności Rumunii nad Besarabią; w jego opinii bowiem musiałoby dojść do nawiązania stosunków dyplomatycznych z Bukaresztem i tym samym otwarcia Królestwa na oddziaływanie „zarazy bolszewickiej”. Bukareszteńskie MSZ w trakcie wymiany zdań z Warszawą nie głosiło oficjalnie tych poglądów. Występowało natomiast ze szczegółowymi zastrzeżeniami odnośnie do paktu. Wskazywano na jego ograniczony zakres czasowy i dwustronny charakter, co stawiało go niżej od paktu Brianda-Kelloga i protokołu Litwinowa, będących układami wielostronnymi o nielimitowanym okresie obowiązywania. Uważano, iż w tej sytuacji pożyteczny dla Bukaresztu byłby raczej traktat o wzajemnej pomocy,

6 H. Walczak, Sojusz z Rumunia w polskiej polityce zagranicznej w latach 1918-1931, Szczecin 2008, s. 458; M. I. Mel'tûhov, Bessarabskij vopros meždu mirovymi vojnami 1917-1940, Moskva 2010, s. 158; M. Gmurczyk-Wrońska, Stanisław Patek w dyplomacji i polityce (1914-1939), Warszawa 2013, s. $385-386$. 
który mógłby stanowić uzupełnienie paktu paryskiego. Mimo tych zarzutów, w Palatul Sturdza dostrzegano jednak także pozytywne elementy polskiej propozycji. Do nich należało zawarcie z ZSRR przez Polskę, Rumunię, Łotwę i Finlandię systemu bilateralnych układów o nieagresji. Zapewnienie ścisłego skorelowania wprowadzenia ich w życie mogłoby stanowić według bukareszteńskiego MSZ widoczny wyraz solidarności państw, składających się na „antysowiecki łańcuch między Bałtykiem i Morzem Czarnym". Korelacja ta podtrzymywała także wartość i znaczenie protokołu moskiewskiego ${ }^{7}$.

W toku dalszej analizy projektu Rumuni wykazywali niepokój, iż pakt mógłby osłabić postanowienia układu paryskiego z $1928 \mathrm{r}$. i protokołu Litwinowa. Ze względu na Besarabię, proponowano zamieszczenie w preambule sformułowania o ,istnieniu stanu pokoju” między sygnatariuszami oraz o "nienaruszalności obecnego terytorium”. Obiekcje budziło też użycie w artykule I określenia „groźba gwałtu”, w którym uznawano ją za sprzeczną $\mathrm{z}$ zasadą nieagresji i godzącą $\mathrm{w}$ „całość, nietykalność terytorium lub niepodległość polityczną". W opinii Rumunów wprowadzenie tego pojęcia stanowiłoby „broń obosieczną”, którą Moskwa mogłaby wykorzystać przeciwko sąsiadom - współsygnatariuszom zawieranych z nią paktów. Np. traktując jako "groźbę gwałtu” przygotowania emigrantów rosyjskich znajdujących się w Rumunii, podejmowane bez wiedzy jej władz i mające na celu zbrojne przekroczenie granicy sowieckiej ${ }^{8}$.

Wiceminister spraw zagranicznych Józef Beck starał się uspokoić obawy Bukaresztu, oznajmiając, iż układ o nieagresji nie nadwyręży znaczenia paktu BriandaKelloga, gdyż jest jego rozwinięciem; poza tym w protokole podpisania wspomina się, iż w razie wygaśnięcia lub przedterminowego wypowiedzenia układu, pakt ten w dalszym ciągu posiada moc obowiązującą. Wiceszef polskiego MSZ zawiadomił o włączeniu do preambuły sformułowania „istnienie stanu pokoju”, natomiast wprowadzenie do niej określenia o „nienaruszalności obecnego terytorium” uznał jako przeszkodę mogącą doprowadzić do fiaska układu. Beck wyraził przekonanie, iż propozycja Warszawy umieszczenia w preambule sformułowania „zachowanie położenia politycznego w Europie Wschodniej”, „jest mniej jaskrawa i ryzykowna” oraz „odpowiada w treści intencjom rządu rumuńskiego”. Ujęcie takie nie przesądzało w jego opinii podjęcia tej sprawy w przyszłości już po podpisaniu paktu o nieagresjị

Pojęcie „groźba gwałtu” stało się przedmiotem dyskusji szefa rumuńskiego Sztabu Generalnego gen. Nicolae Samsonovici z gen. Tadeuszem Piskorem - jego polskim

7 G. Gafencu, Însemnări politice 1929-1939, oprac. i posłowie S. Neagoe, Bucureşti 1991, s. 232 (pierwszy cytat); memorandum Ariona do Ghiki i Ministerstwa Wojny z 15 V 1931, Behind closed doors. Secret papers on the failure of Romanian-Soviet negotiations 1931-1932, tłum. i wstęp W. M. Bacon, Stanford 1979, s. 27-30 (pozostałe cytaty); Â. M. Kopanskij, I. Ė. Levit, Sovetsko-rumynskie otnošeniâ 1929-1934 gg. (od podpisania Moskovskogo protokola do ustanovleniâ diplomatičeskih otnošenij), Moskva 1971, s. 78; T. Sandu, Système de sécurité français en Europe centre-orientale. L'exemple roumain 1919-1933, Paris-Montréal 1999, s. 369-370.

8 H. Walczak, op. cit., s. 459.

9 Ibidem, s. 459. 
odpowiednikiem, w czasie wizyty w Warszawie w dniach 25 czerwca-1 lipca 1931 roku. Ustalono wówczas zasadność usunięcia $\mathrm{z}$ artykułu I, akapitu 2 sformułowania „groźba gwałtu”. Ku zaskoczeniu gospodarzy rumuński gość chciał powrócić do kwestii „nienaruszalności obecnego terytorium” oraz wystąpił z inicjatywą zaproszenia Turcji i Persji do grona państw zawierających pakty o nieagresji ze Związkiem Sowieckim. W sprawach tych nie doszło do żadnych ustaleń. W pierwszej kwestii - jak twierdził Beck - minister Ghica już wcześniej przyjął polski punkt widzenia, a $\mathrm{z}$ Turcją i Persją Moskwa podpisała układy o nieagresji odpowiednio w 1925 i 1927 roku. W związku z tym wiceszef polskiej dyplomacji podejrzewał, iż gen. Samsonovici nie uzgadniał swoich poglądów z gospodarzem Palatul Sturdza ${ }^{10}$.

Postępujące negocjacje francusko-sowieckie w sprawie paktu o nieagresji, zainteresowanie państw bałtyckich zawarciem podobnego układu z Moskwą i ich zaniepokojenie opóźnianiem się pertraktacji polsko-sowieckich determinowały aktywność Warszawy w tej materii. Istotne dla jej planów stworzenia wspólnego frontu zachodnich sąsiadów ZSRR było wyjaśnienie stanowiska Bukaresztu. Strona polska żywiła nadzieję, iż Rumuni przedstawią w sposób szczegółowy swoją opinię wobec rozwiązań zawartych w polskim projekcie albo przedstawią własny kontrprojekt. 9 lipca 1931 r. odbyła się rozmowa między posłem RP w Bukareszcie a ministrem Ghiką. Gospodarz Palatul Sturdza zaprezentował skrajny pesymizm odnośnie do możliwości zawarcia rumuńsko-sowieckiego układu o nieagresji. Główną przeszkodę widział on w małych szansach uzgodnienia konwencji arbitrażowej, mającej być elementem składowym tego układu, ze względu na obawę poddania procedurze rozjemczej sprawy besarabskiej. Aby uchronić się przed ewentualnymi pretensjami Polski o storpedowanie działań służących „ugruntowaniu pokoju”, rumuński minister stwierdził, że „przyjmuje z wdzięcznością” pośrednictwo Warszawy w sprawie podjęcia rozmów. Wynurzenia Ghiki nie wychodziły - jak zauważył Szembek - „poza ogólne zasady" i nie podejmowały meritum polskiego projektu. Poseł przewidywał, iż Rumuni nie zdołali wypracować jeszcze własnego kontrprojektu ${ }^{11}$.

Swego rodzaju podsumowaniem dyskusji były zmiany i doprecyzowania wprowadzone w polskim projekcie paktu, idące po linii oczekiwań Rumunów, a nawet wychodzące poza nie, o czym Szembek zawiadomił 24 lipca Gheorghe Filality’ego - sekretarza generalnego bukareszteńskiego MSZ - i uzyskał jego akceptację. W artykule I, ustęp 2 po wyrażeniu „wszelki akt gwałtu” usunięto słowa „lub groźba gwałtu”. We wstępie w ustępie 3 po słowach „ożywieni pragnieniem” wprowadzono frazę „utrwalenia istniejącego między ich krajami pokoju”; w ustępie 5 po słowach „sporów międzynarodowych” włączono fragment ,i unikanie wszystkiego, co mogłoby się sprzeciwić normalnemu stanowi stosunków między państwami". W rezultacie tekst odnośnego fragmentu preambuły przyjął następujące brzmienie: „Prezydent

10 Ibidem, s. 466.

11 Telegram Szembeka do MSZ z 10 VII 1931 (nr 72). HIA. Rumunia. Ks. szyf., nr 5, p. 2, f. 2; wyciąg z raportu Szembeka z 11 VII 1931, Archiwum Akt Nowych (dalej: AAN), Sztab Główny, 616, T. 90 , k. 174-175. 
Rzeczypospolitej Polskiej z jednej i Centralny Komitet Wykonawczy Związku Socjalistycznych Sowieckich Republik - z drugiej strony, ożywieni pragnieniem utrwalenia istniejącego między ich krajami pokoju [i] umocnienia drogą bezpośredniego porozumienia politycznego położenia w Europie wschodniej, uznając, że traktat pokoju z 18 marca 1921 r. stanowi podstawę ich stosunków i zobowiązań, są przekonani, że pokojowe załatwianie sporów międzynarodowych i unikanie wszystkiego, co mogłoby się sprzeciwić normalnemu stanowi stosunków między państwami, jest najpewniejszym środkiem do osiągnięcia zamierzonego celu"12.

Rumuńska wersja paktu o nieagresji 25 sierpnia została przekazana posłowi Szembekowi. Tworzyła ją: preambuła i siedem artykułów, z których II i III miały identyczne brzmienie jak w polskim projekcie. We wstępie obaj sygnatariusze deklarowali pragnienie utrzymania istniejącego stanu pokoju oraz umocnienia sytuacji politycznej w Europie Wschodniej, wyrażając przekonanie, iż rozwiązywanie wszelkich konfliktów, które mogłyby powstać między nimi, powinno się dokonywać tylko drogą pokojowego postępowania; stąd też postanowili zawrzeć traktat mający za cel rozszerzenie i uzupełnienie paktu Brianda-Kelloga (bez modyfikowania w czymkolwiek jego podstawy) i protokołu moskiewskiego. Artykuł I stanowił o wyrzeczeniu się wojny jako narzędzia polityki narodowej we wzajemnych relacjach obu państw oraz formułował obietnicę wzajemnego powstrzymywania się przed wszelkimi agresywnymi działaniami lub najazdem przeciw drugiej stronie. Za działania sprzeczne z tymi zobowiązaniami uznawano wszelki akt gwałtu zagrażający aktualnej terytorialnej integralności i obecnej politycznej niepodległości drugiej strony, nawet jeśli byłyby one popełnione bez wypowiedzenia wojny. W artykule IV sygnatariusze deklarując rozwiązywanie wszelkich kwestii spornych drogą pokojową, obiecywali czynić to za pomocą koncyliacji i arbitrażu zgodnie z klauzulami Konwencji Koncyliacji i Arbitrażu, stanowiącej integralną część paktu; jednocześnie z procedury tej wykluczano: a) wszelkie kwestie wynikające $z$ sytuacji lub faktów wcześniejszych, zaistniałych do ratyfikacji przez rumuński parlament Konwencji Koncyliacji i Arbitrażu, b) wszelkie sprawy mogące prowadzić, bezpośrednio lub pośrednio, do dyskusji o obecnej integralności terytorialnej i suwerennych prawach Rumunii, w tym dotyczące jej portów i linii komunikacyjnych, c) spory odnośnie do zagadnień, które zgodnie z prawem międzynarodowym pozostają pod jurysdykcją Rumunii. W artykule $\mathrm{V}$ obie strony zgadzały się na zaproszenie rządów, które podpisały protokół Litwinowa, w tym Finlandii, do zawarcia analogicznych układów z ZSRR. Artykuł VI oznajmiał o wejściu w życie traktatu po 30 dniach od notyfikacji Polsce (Rumunii) przez ZSRR, że doszło do zawarcia przezeń i ratyfikowania analogicznych porozumień z Estonią, Finlandią, Łotwą, Litwą, Persją, Rumunią (Polską)

12 Telegram Becka do poselstwa w Bukareszcie z 17 VII 1931, nr 66, HIA. Rumunia. Ks. szyf., nr 5, p. 2, f. 2; telegram Szembeka do MSZ z 21 VIII 1931, nr 92, ibidem; Projekt paktu o nieagresji wręczony przez posła RP w Moskwie St. Patka [23 sierpnia 1931] zastępcy komisarza ludowego spraw zagranicznych ZSRR L. Karachanowi. Dokumenty i materiały do historii stosunków polskoradzieckich (dalej: DMHSPR), t. V, maj 1926-grudzień 1932, oprac. T. Cieślak i in., Warszawa 1966, s. 547-549, zob. G. Gafencu, op. cit., s. 286-287. 
i Turcją. Artykuł VII występował w projekcie w dwóch wersjach. W pierwszej czas trwania układu ustalono podobnie jak pakt paryski i protokół Litwinowa na czas nieograniczony. Według drugiej wersji traktat miał obowiązywać pięć lat i mógł być milcząco przedłużany na taki sam okres, jeśli na rok przed upływem tego terminu nie zostałby wypowiedziany przez żadną ze stron ${ }^{13}$.

Po zaznajomieniu się z tekstem rumuńskim i skonstatowaniu „kilku «dość istotnych» różnic" w stosunku do projektu polskiego, Szembek poprosił o pilne spotkanie z Ghiką, opóźniając swój wyjazd na urlop do Polski. W rozmowie, do której doszło 27 sierpnia poseł RP stwierdził, iż szkic rumuński zbyt daleko odbiega od projektu polskiego, szczególnie w odniesieniu do wzmianek o kwestiach terytorialnych, których należało unikać za wszelką cenę, gdyż mogłyby one spowodować od początku kategoryczną odmowę prowadzenia pertraktacji przez ZSRR. Szembeka niepokoił zwłaszcza artykuł IV, mówiący o wyłączeniu spod arbitrażu lub koncyliacji konkretnych kwestii, które mogłyby doprowadzić bezpośrednio lub pośrednio do dyskusji o obecnej terytorialnej integralności Rumunii. Poseł RP uważał, iż osiągnięcie tego celu było możliwe bez wprowadzania tych zastrzeżeń do treści paktu. W jego przekonaniu należało dokonać zmiany preambuły, dostosowując do jej ogólnego brzmienia zmodyfikowany artykuł IV, stanowiący, iż z postępowania koncyliacyjnego i arbitrażowego będą wykluczone te kwestie, które zostały wyraźnie zarezerwowane przez Rumunię przy okazji jej przystąpienia do artykułu 36 Statutu Stałego Trybunału Sprawiedliwości Międzynarodowej (były one identyczne z zastrzeżeniami wymienionymi w pierwotnej wersji artykułu IV). W ten sposób zdaniem Szembeka żadna z bezpośrednich wzmianek o kwestiach terytorialnych, która mogłaby posłużyć do sprowokowania „non possumus” ze strony Moskwy, nie figurowałaby w tekście traktatu, a jednocześnie Rumunia zachowałaby prawo odmowy poddania arbitrażowi sprawy Besarabii.

Poseł RP zwrócił również uwagę ministra Ghiki na różnice między polskim a rumuńskim projektem w artykułach V i VI. Stwierdził on, iż nie wie, czy Finlandia weźmie udział w „systemie proponowanych traktatów” i że nie wierzy w możliwość włączenia Persji i Turcji, gdyż państwa te zawarły „podobne traktaty z ZSRR”. W odniesieniu do Litwy natomiast dawał do zrozumienia, że rząd RP nie dopuszcza możliwości jej uczestnictwa. W zgodnej opinii Szembeka i Ghiki te ostatnie różnice nie miały wielkiego znaczenia i mogły zostać łatwo wyrównane. Choć poseł RP wyrażał zaniepokojenie artykułem IV, to jednak obiecał poinformować Warszawę, że Rumunia absolutnie domaga się, ażeby jednoznacznie wyjaśniono w tekście zaproponowanym ZSRR, że kwestia Besarabii nigdy nie będzie bezpośrednio lub pośrednio przedmiotem arbitrażu. W trzy dni później polski chargé d’affaires w Bukareszcie Dembiński poinformował Rumunów, iż ich zastrzeżenia zawarte w artykule IV nie tworzyłyby nieprzezwyciężonej trudności w negocjacjach i kwestia ta mogłaby zostać rozwiązana w sposób dla nich zadowalający ${ }^{14}$.

13 Rumuński projekt traktatu o nieagresji z ZSRR z 25 VIII 1931, Behind..., s. 34-36; T. Sandu, op. cit., s. 373; zob. też Â. M. Kopanskij, I. Ė. Levit, op. cit., s. 78.

14 Memorandum Cretzianu z 27 VIII 1931, Behind..., s. 37-39. 
Zamiarom dyplomacji polskiej dotyczącym skorelowania z rozmowami francusko-sowieckimi ${ }^{15}$ negocjacji z ZSRR o pakt o nieagresji stanęły na przeszkodzie incydenty z zakresu relacji bilateralnych (m.in. afera szpiegowska mjr. Wojska Polskiego Piotra Demkowskiego ${ }^{16}$, niechęć władz polskich odnośnie do wymiany informacji o siłach zbrojnych ${ }^{17}$ ) powodujące zadrażnienia na linii Warszawa-Moskwa, a także opory Narodnogo komissariata inostrannyh del SSSR (dalej: NKID) - Ludowego Komisariatu Spraw Zagranicznych ZSRR (dalej: LKSZ) niewierzącego w gotowość RP na zasadniczą poprawę stosunków z Sowietami. W rezultacie poseł Patek miał okazję przedstawić stronie sowieckiej projekt paktu ${ }^{18}$ dopiero 23 sierpnia $1931 \mathrm{roku}^{19}$.

Inicjatywa Patka spotkała się w kierownictwie NKID z mało przychylnym przyjęciem. Dalej obowiązywała tam opinia o braku gotowości Polski do zasadniczej poprawy stosunków z Sowietami, a działania posła RP tłumaczono względami propagandowymi oraz bieżącą polityką. Odmienny punkt widzenia reprezentował Sekretarz Generalny WKP(b) Józef Stalin, który opowiadał się za negocjacjami z Polską, uzasadniając zawarcie paktu koniecznością zachowania pokoju i fundamentalnymi interesami państwa sowieckiego. Pogląd ten zwyciężył i Politbiuro nakazało Litwinowowi przygotowanie odpowiedniego oświadczenia. Tymczasem Francuzi naciskali zarówno na Warszawę, jak i Moskwę w celu szybkiego podjęcia rozmów. Pragnęli, aby podpisanie francusko-radzieckiego paktu zostało poprzedzone lub skorelowane z zawarciem analogicznego porozumienia polsko-radzieckiego. Mimo obiekcji Rosjanie w końcu przyjęli ten warunek i 14 października Ludowy Komisarz Spraw Zagranicznych Maksim Litwinow oficjalnie poinformował polskiego chargé d’affaires Adama Zielezińskiego o gotowości rządu sowieckiego do podpi-

1510 sierpnia 1931 r. został parafowany w Paryżu francusko-sowiecki pakt o nieagresji. M. Wołos, op. cit., s. 513; F. Dessberg, Le triangle impossible. Les relations franco-soviétiques et le facteur polonais dans les questions de sécurité en Europe (1924-1935), Bruxelles 2009, s. 278.

16 Szerzej: A. Pepłoński, Kontrwywiad II Rzeczypospolitej, Warszawa 2002, s. 276-285; A. Krzak, Kontrwywiad wojskowy II Rzeczpospolitej przeciwko radzieckim służbom specjalnym 1921-1939, Toruń 2007, s. 251-256.

17 W lutym 1931 r. Sekretarz Generalny Ligi Narodów Eric Drummond rozesłał ankietę dotyczącą stanów zbrojeń państw mających uczestniczyć w Konferencji Rozbrojeniowej. Dane przedstawione przez ZSRR były bardzo ogólne w porównaniu do danych innych państw i trudne do zweryfikowania. Ze względu na szczególną sytuację Polski jako sąsiada ZSRR, Wierzbowa zwróciła się do Sekretarza Ligi, aby spowodował uzupełnienie tych danych przez Rosjan. Ostatecznie strona sowiecka zadeklarowała gotowość przekazania Polakom, na zasadzie wzajemności, informacji o swoich zbrojeniach. W. Michowicz, Genewska Konferencja Rozbrojeniowa 1932-1937 a dyplomacja polska, Łódź 1989, s. 107-109.

18 Projekt ten zawierał wszystkie wcześniejsze zmiany uzgodnione z Rumunami, a także nową redakcję 6 i 7 artykułu oraz protokołu podpisania. Projekt paktu o nieagresji..., DMHSPR, t. V, s. 547-549.

19 Sprawozdanie Davidescu do MSZ z 28 VIII 1931. Arhivele Ministerului Afacerilor Externe, București (dalej: AMAE). 71/1920-1944 U.R.S.S. Vol. 68, k. 93-96; O. Ken, Moskva i pakt nenapadeniâ s Pol’šej (1930-1932), Sankt Petersburg 2003, s. 20-21; M. Gmurczyk-Wrońska, Negocjacje polskosowieckie o pakt o nieagresji w roku 1927 i w latach 1931-1932, „Dzieje Najnowsze”, 2012, nr 3, s. 39; zob. też telegram Bilciurescu do MSZ z 27 VIII 1931, nr 2603. AMAE. 71/1920-1944, U.R.S.S. Vol. 68, k. 91; Â. M. Kopanskij, I. Ė. Levit, op. cit., s. 79; M. I. Mel'tûhov, op. cit., s. 158. 
sania z Polską takiego samego paktu jak parafowany z Francją (10 sierpnia), na co rzekomo dał zgodę polski minister spraw zagranicznych August Zaleski w rozmowie z Sekretarzem Generalnym francuskiego MSZ - Philppe Berthelotem ${ }^{20}$.

Kilka dni wcześniej poseł sowiecki w Polsce Władimir Antonow-Owsiejenko, sondując - jak można sądzić - stanowisko polskiego MSZ, wyraził opinię, iż projekt złożony przez Patka 23 sierpnia jest nie do przyjęcia dla rządu sowieckiego, z powodu stypulacji warunkującej wejście w życie paktu zawarciem przez ZSRR podobnych układów z Rumunią i państwami bałtyckimi. Przyjęcie takiego rozwiązania przez rząd sowiecki prowadziłoby - zdaniem posła - za sprawą samego Związku Sowieckiego do wzmocnienia wrażenia, iż jego zachodni sąsiedzi tworzą antyradziecki blok. Owsiejenko uważał też za szczególnie niemożliwe podpisanie paktu o nieagresji z Rumunią, gdyż oznaczałoby to milczącą zgodę Moskwy na zrzeczenie się Besarabii. W jego opinii jedynym sprawiedliwym sposobem rozwiązania tej kwestii byłoby przeprowadzenie tam plebiscytu, po uprzedniej ewakuacji Rumunów ${ }^{21}$.

Polska nie zamierzała jednak zmieniać swego stanowiska. Poinformowano o tym Francuzów. A zaniepokojonych Rumunów starał się uspokoić i przekonać Marszałek Piłsudski w czasie swojej wizyty w Rumunii (11-29 października) ${ }^{22}$, gdzie w rozmowie z ministrem Ghiką (15 października) przedstawił sprawę, informując jednocześnie o zobowiązaniu Francji do niepodpisywania paktu z ZSRR bez synchronizacji z Polską. 3 listopada, w dniu wyjazdu Patka do Moskwy, Beck polecił poinformować Bukareszt, iż dyplomacja RP w przyszłych negocjacjach o pakt o nieagresji będzie stała na stanowisku uzgodnień poczynionych wcześniej z Rumunami, z pełnym zachowaniem swoich zobowiązań sojuszniczych ${ }^{23}$.

14 listopada doszło do spotkania Patka z Litwinowem. Poseł RP zdystansował się od prowadzenia rokowań w oparciu o parafowany pakt sowiecko-francuski, wyjaśniając, iż rzekoma deklaracja Zaleskiego była skutkiem nieporozumienia ${ }^{24}$. Jako podstawę negocjacji zaproponował złożony przez siebie 23 sierpnia projekt,

20 O. Ken, op. cit., s. 45 i n.; M. Wołos, op. cit., s. 530-535; A. Skrzypek, Polsko-radziecki pakt..., s. 19-20; M. Gmurczyk-Wrońska, Negocjacje..., s. 40-42.

21 Telegram Bilciurescu do premiera N. Iorgi z 5 X 1931 (nr 3024). AMAE. 71/1920-1944 U.R.S.S. Vol. 68, k. 102-102a.

22 Szerzej o wizycie W. Jędrzejewicz, J. Cisek, Kalendarium życia Józefa Piłsudskiego 1867-1935, t. 3, 1926-1935, Wrocław 1994, s. 224-225; M. Lepecki, Pamiętnik adiutanta Marszałka Piłsudskiego, oprac. nauk. i przedm. A. Garlicki, Warszawa 1987, s. 54 i n.; F. Anghel, Mareşalul Piłsudski în „peţit la Bucureşti”, „Magazin Istoric”, 1997, nr 9, s. 73-75.

23 Telegramy Becka do Szembeka z 16 X (nr 104), 2 XI (nr 119), 3 XI (nr 120) 1931, HIA. Rumunia. Ks. szyf., nr 5, p. 2, f. 2; telegram Szembeka do MSZ z 19 X 1931, ibidem; D. Ghyka, Memorii (1894-1940), Iași 2004, s. 307; F. Dessberg, La Roumanie, s. 69; M. Wołos, op. cit., s. 533; H. Bułhak, Polska a Rumunia 1918-1939, [w:] Przyjaźnie i antagonizmy. Stosunki Polski z państwami sąsiednimi w latach 1918-1939, red. J. Żarnowski, Warszawa 1977, s. 328-329.

24 W czasie spotkania z Berthelotem 5 października $1931 \mathrm{r}$. Zaleski pozytywnie ocenił pakt francusko-radziecki oraz wyraził uznanie dla postawienia iunctim pomiędzy zawarciem tego paktu a podpisaniem analogicznego układu polsko-sowieckiego. Sekretarz Generalny Quai d’Orsay potraktował to jako zgodę polskiego ministra na przyjęcie paktu francusko-sowieckiego jako podstawy negocjacyjnej w przyszłych rozmowach polsko-sowieckich. M. Wołos, op. cit., s. 530-538. 
który stanowił uzupełnioną wersję projektu NKID z 1926 roku $^{25}$. Życzeniem Polski było zawarcie przez ZSRR paktów o nieagresji „na całej linii”, ze wszystkimi jego zachodnimi sąsiadami. Obok RP byłyby to Finlandia, Estonia, Łotwa i Rumunia. Strona radziecka nie protestowała przeciwko temu. Pragnęła jednak z każdym z państw prowadzić rokowania bezpośrednie i tylko w zakresie go dotyczącym. Nie chciała się natomiast zgodzić na oficjalne pośrednictwo Polski w rokowaniach z tymi krajami, „protektorat” nad nimi Warszawy oraz zawarcie paktu „na żądanie” RP. Ze względu na brak stosunków dyplomatycznych z Rumunią, Litwinow oczekiwał od Bukaresztu inicjatywy w sprawie podpisania paktu. Deklarując jej życzliwe przyjęcie, zastrzegał jednak, iż nie mogłoby się to wiązać ze zmianą sytuacji kwestii besarabskiej. Ludowy komisarz zaznaczył, iż Moskwa nie zamierza rozstrzygać jej drogą zbrojną i zdawał się przyjmować sugestię Patka, by sprawę w przyszłych rokowaniach pozostawić „na boku”26.

Wierzbowa przyjęła sowieckie zastrzeżenia. W opinii Becka wobec niemożności zrealizowania zasady „okrągłego stołu”, istotną wartość dla Polski stanowił „fakt zawarcia takiego paktu równocześnie”. W związku z tym Patek otrzymał polecenie odpowiedniej modyfikacji artykułu VI projektu. 20 listopada Biuro Polityczne KC WKP(b) zdecydowało o podjęciu rokowań na podstawie polskiego projektu ${ }^{27}$.

Dyplomacja polska szczegółowo informowała Bukareszt o dotychczasowym przebiegu rozmów z Rosjanami. Inicjatywa wystąpienia przez Rumunów wobec Moskwy z propozycją rokowań wydawała się polskiemu MSZ rozwiązaniem korzystnym. Dlatego też Beck zaoferował im wysunięcie wobec NKID sugestii, aby negocjacje prowadził w Warszawie poseł Grigore Bilciurescu mając za partnera Antonowa Owsiejenkę ${ }^{28}$.

25 Szerzej o wcześniejszych negocjacjach polsko-sowieckich o pakt o nieagresji zob. S. Gregorowicz, M. J. Zacharias, Polska-Związek Sowiecki: stosunki polityczne w latach 1925-1939, Warszawa 1995, s. 25 i n.; M. Leczyk, Polityka..., s. 105 i n.; W. Materski, Na widecie. II Rzeczpospolita wobec Sowietów 1918-1943, Warszawa 2005, s. 293 i n.; M. Gmurczyk-Wrońska, Negocjacje..., s. 21 i n.

26 Notatka Komisarza ludowego z 14 XI 1931, DMHSPR, t. V, s. 558-561; raport Patka z 16 XI 1931, ibidem, s. 562-565 (to samo: Polskie Dokumenty Dyplomatyczne 1931, red. M. Wołos, Warszawa 2008, s. 708-711 (dalej: PDD) oraz S. Patek, Raporty i korespondencja z Moskwy (1927-1932), wstęp, wybór i oprac. M. Gmurczyk-Wrońska, Warszawa 2010, s. 451-454); telegram Schaetzela do Szembeka z 15 XI 1931 (nr 122); telegram Becka do Szembeka z 16 XI 1931, nr 123, HIA. Rumunia. Ks. szyf., nr 5, p. 2, f. 2; A. Skrzypek, Polsko-radziecki pakt..., s. 20-21; M. Wołos, op. cit., s. 538-540; Â. M. Kopanskij, I. Ė. Levit, op. cit., s. 79; M. I. Mel'tûhov, op. cit., s. 158.

27 Telegramy Becka do poselstwa w Bukareszcie z 16 XI (nr 123) i 22 XI (nr 124) 1931, HIA. Rumunia. Ks. szyf., nr 5, p. 2, f. 2; O. Ken, A. I. Rupasov, Politbûro CK VKP(b) i otnošeniâ SSSR $s$ zapadnymi sosednimi gosudarstvami (konec 1920-1930- $h$ gg.): Problemy. Dokumenty. Opyt kommentariâ, Čast' 1: 1928-1934, Sankt Petersburg 2000, s. 274-276.

28 Telegram Becka do poselstwa w Bukareszcie z 16 XI 1931, nr 123, HIA. Rumunia. Ks. szyf., nr 5, p. 2, f. 2; telegram Bilciurescu do MSZ z 21 XI 1931, nr 3863, AMAE. 71/1920-1944 U.R.S.S. Vol. 68, k. 103; raport Bilciurescu do Ghiki z 21 XI 1931, nr 3864, Behind..., s. 39-41; raport Bilciurescu do Ghiki z 22 XI 1931, AMAE. 71/1920-1944 U.R.S.S. Vol. 68, k. 104-106; zob. też raport Davidescu do Ghiki z 26 XI 1931, nr 3946, ibidem, k. 107-107a. 
Ghica odniósł się do informacji o propozycji Rosjan przekazanych mu przez Szembeka z nieufnością. W jego opinii miała ona doprowadzić do rozdzielenia Polski i Rumunii. Wyraził też obawę, że dyplomaci sowieccy mogliby na początku rokowań postawić sprawę Besarabii „dla Rumunii definitywnie zamkniętej” i zażądać przeprowadzenia plebiscytu, co nieuchronnie musiałoby doprowadzić do zerwania pertraktacji. Poseł RP argumentował, iż w propozycji Rosjan nie dostrzega chęci rozdzielenia sojuszników, ponieważ zwrócili się oni do Rumunów za pośrednictwem Polski, a nie przez inne państwo. Szembek wskazał na sprzyjający moment dla podjęcia negocjacji ze względu na konflikt w Mandżurii, stwarzający zagrożenie dla interesów ZSRR na Dalekim Wschodzie i angażujący jego uwagę. Ghica wydawał się przekonany. Uznał on za pożyteczne podpisanie układu z ZSRR „w rodzaju paktu Litwinowa”. W Palatul Sturdza traktowano go jako element składowy systemu paktów o nieagresji, służących utrzymaniu solidarności między państwami tworzącymi „antysowiecki łańcuch od Bałtyku do Morza Czarnego”. Pomysł Becka odnośnie do prowadzenia negocjacji z Rosjanami przez Bilciurescu ocenił Ghica jednak krytycznie, podnosząc jego brak zręczności dyplomatycznej i niebezpieczeństwo spowodowania przez to fiaska rokowań. Gotów był natomiast dać Bilciurescu i rumuńskiemu chargé d'affaires w Rydze, Mihaiowi Sturdzy, instrukcje w sprawie podjęcia sondażowych rozmów z dyplomatami sowieckimi odnośnie do miejsca, osoby i terminu rozpoczęcia rokowań. Rumuńskiemu ministrowi zależało również na doprecyzowaniu zakresu rozmów i sposobu ich prowadzenia. Nie chciał on powtórzenia sytuacji z okresu rokowań wiedeńskich z 1924 r., które Rosjanie wykorzystali dla hałaśliwej propagandy przeciwko Rumunii, stawiając ją w kwestii besarabskiej w upokarzającej roli oskarżonego ${ }^{29}$.

$\mathrm{W}$ przededniu rozpoczęcia rozmów sondażowych $\mathrm{z}$ dyplomatami ZSRR istotne dla Ghiki było stanowisko Francji. Indagowany w końcu listopada przez posła Constantina Cesianu, Berthelot stwierdził, że rząd francuski nie tylko nie wyraża żadnych sprzeciwów odnośnie do bezpośredniego kontaktu między Rumunią a Związkiem Radzieckim, ale w przypadku ich niepowodzenia zobowiązania Paryża wobec Bukaresztu pozostaną niezmienione. Moment dla podjęcia rokowań był według Francuzów szczególnie odpowiedni ze względu na kłopoty Rosjan na Dalekim Wschodzie. W trakcie wspomnianej rozmowy z Cesianu, Sekretarz Generalny Quai d'Orsay przedstawił posłowi rumuńskiemu tekst parafowanego paktu francusko-sowieckiego i zaoferował ewentualną pomoc poselstwa francuskiego w Rydze w nawiązaniu kontaktu przez rumuńskiego chargé d’affaires z sowieckim przedstawicielem ${ }^{30}$.

29 Telegramy Szembeka do MSZ z 19 XI (nr 123) i 22 XI (nr 124) 1931, HIA. Rumunia. Ks. szyf., nr 5, p. 2, f. 2; memorandum Ariona z 23 XI 1931, Behind..., s. 41-42; pismo Ghiki do poselstwa w Warszawie z 28 XI 1931, Behind..., s. 43; zob. D. Ghyka, op. cit., s. 306.

30 Telegram Szembeka do MSZ z 28 XI 1931, nr 134, HIA. Rumunia. Ks. szyf., nr 5, p. 2, f. 2; pismo Ghiki do poselstwa w Warszawie z 28 XI 1931, Behind..., s. 43; telegram Cesianu do MSZ z 2 XII 1931, nr 882, AMAE. 71/1920-1944 U.R.S.S. Vol. 68, k. 110; zob. też Â. M. Kopanskij, I. È. Levit, op. cit., s. 79; A. Ševâkov, op. cit., s. 21; T. Sandu, op. cit., s. 374. 
Skłanianie się rządu rumuńskiego pod wpływem dyplomacji polskiej i francuskiej do rozmów z Sowietami nie było równoznaczne z pozbyciem się wahań, sygnalizowanych wcześniej przez Ghikę w rozmowie z Szembekiem. Udział w tych wahaniach miała również rumuńska opinia publiczna oraz opozycja parlamentarna (przede wszystkim partia liberalna), niechętne porozumieniu z Sowietami. Szembek obawiał się, aby sposób negocjowania przez Polskę i Rumunię paktów o nieagresji z ZSRR, przedstawiany nad Dambovitą jako pozostawienie Bukaresztu własnemu losowi, nie wpłynął negatywnie na stan relacji miedzy sojusznikami. W celu uspokojenia rządu królewskiego Szembek został zobligowany do przypomnienia, iż w prowadzonych z ZSRR rozmowach Patek ustalił, że sprawa Besarabii będzie w trakcie rokowań rumuńsko-sowieckich pozostawiona „na boku”, a kolportowana na gruncie bukareszteńskim interpretacja, że miałaby ona pozostać „otwarta”, jest niezgodna z prawdą. Poseł RP miał stwierdzić wobec Palatul Sturdza, iż trzeba będzie brać pod uwagę, iż w trakcie rokowań Rumunii z Sowietami dojdzie do ich jednostronnej deklaracji w kwestii Bessarabii, ale w żadnym razie nie zmieni ona „ani dzisiejszego ani prawnego stanu” tej prowincji. Warto też, aby Rumuni pamiętali o oświadczeniu Litwinowa względem Patka, iż Związek Sowiecki nie zamierza zbrojnie rozstrzygać sprawy Besarabii ${ }^{31}$. Z kolei w rozmowach z opozycją parlamentarną poseł RP wskazywał, iż pakt polsko-sowiecki będzie służyć odprężeniu stosunków między tymi państwami oraz zneutralizowaniu propagandy rozwijanej w społeczeństwie sowieckim o zagrożeniu ZSRR przez polską interwencję i w żadnym razie nie osłabi znaczenia umów sojuszniczych, które w Warszawie uważano „za cenniejsze i realniejsze (...) niż pakty o nieagresji”. Zawarcie paktu rumuńsko-sowieckiego uznawała Wierzbowa za bardzo wskazane dla koordynacji funkcjonowania aliansu polsko-rumuńskiego wobec ZSRR, stabilizacji stosunków Moskwa-Bukareszt oraz realizacji koncepcji zawarcia przez limitrofów „paktów równoległych” (tym bardziej że Estonia i Finlandia zadeklarowały już gotowość rozmów ze Związkiem Sowieckim) ${ }^{32}$.

Ze względów oczywistych Polska pragnęła dyskretnie pośredniczyć w pertraktacjach sowiecko-rumuńskich. W ówczesnej sytuacji sprawa miejsca i osoby wydawała się nie mieć dla niej znaczenia. Dlatego też na Wierzbowej przyjęto obojętnie enuncjację Ghiki dezawuującą kandydaturę Bilciurescu jako rumuńskiego negocjatora, deklarując jednocześnie chęć udzielenia pomocy Sturdzy w Rydze w zaaranżowaniu rozmów sondażowych z miejscowym sowieckim przedstawicielem ${ }^{33}$.

31 Telegram Schaetzela do Bukaresztu z 1 XII 1931, nr 131, HIA. Rumunia. Ks. szyf., nr 5, p. 2 , f. 2; pismo Ghiki do poselstwa w Warszawie z 28 XI 1931, Behind..., s. 43; telegram Szembeka do MSZ z 5 XII 1931, nr 137, HIA. Rumunia. Ks. szyf., nr 5, p. 2, f. 2; G. Gafencu, op. cit., s. 285-286; M. I. Mel'tûhov, op. cit., s. 158-159.

32 Telegram Becka do Bukaresztu z 30 XI 1931, nr 129 (stąd cytaty), HIA. Rumunia. Ks. szyf., nr 5, p. 2, f. 2; telegram Szembeka do MSZ z 28 XI 1931, nr 134, ibidem; telegram Zaleskiego do Bukaresztu z 5 XII 1931, nr 134, ibidem; G. Gafencu, op. cit., s. 286.

33 Telegramy Becka do Bukaresztu z 26 XI (nr 127) i 30 XI (nr 128) 1931, HIA. Rumunia. Ks. szyf., nr 5, p. 2, f. 2 . 
Można sądzić, iż strona polska zrozumiała oświadczenie Ghiki odnośnie do Bilciurescu nie tylko jako odrzucenie jego kandydatury na rumuńskiego negocjatora do rokowań z ZSRR, ale też jako wyłączenie go z prowadzenia sondaży z Owsiejenką. Tymczasem 2 grudnia Bilciurescu nawiązał w tej ostatniej kwestii kontakt z ministrem Zaleskim, który inicjatywę tę przyjął z pewnym niepokojem, obawiając się, czy akcja rumuńska prowadzona jednocześnie via Ryga i Warszawa nie spowoduje chaosu. Wątpliwościami tymi szef polskiej dyplomacji podzielił się także z Quai d'Orsay, licząc być może na interwencję $\mathrm{z}$ tej strony w Bukareszcie ${ }^{34}$.

Jak się wydaje, Ghica, nie w pełni ufając polskiej dyplomacji, nie chciał się zdawać jedynie na nią w kwestii pośrednictwa w sondażach. $Z$ jego polecenia, a bez informowania Wierzbowej Ion Carp - poseł rumuński w Ankarze oraz Sturdza - chargé d’affaires w Rydze podjęli takie akcje. 1 grudnia Carp spotkał się z Tevfikiem Rüştü Arasem - tureckim ministrem spraw zagranicznych, od którego usłyszał, że Rosjanie są gotowi podjąć negocjacje z Rumunią, jeśli inicjatywa wyjdzie od niej, a pośrednikiem $\mathrm{w}$ ich nawiązaniu będzie państwo niezainteresowane bezpośrednio w relacjach sowiecko-rumuńskich. Rüştü Aras wyraził także sugestię, że Moskwa oczekiwałaby jako warunku sfinalizowania negocjacji wypowiedzenia przez Rumunię sojuszu z Polską, za cenę możliwości porozumienia w kwestii Besarabii. Informacje te Ghica przyjął z dużym zaniepokojeniem. W rozmowie z Szembekiem ponownie zaczął podnosić, iż skłonności Moskwy do zawarcia paktu o nieagresji są jedynie manewrem zmierzającym do rozbicia polsko-rumuńskiego aliansu. W rezultacie zamiary ciągle wahającego się szefa rumuńskiej dyplomacji w kwestii podjęcia negocjacji z Moskwą uległy znacznemu osłabieniu.

Dyplomacja polska zareagowała na zaistniałą sytuację z pewną irytacją, wyrażając zdziwienie, że Ghica podjął zabiegi nawiązania kontaktów z ZSRR za pośrednictwem szefa tureckiej dyplomacji, wykazującego już od pewnego czasu inklinacje do osłabienia sojuszu polsko-rumuńskiego. Z drugiej jednak strony Wierzbowa usiłowała uspokoić Rumunów. Wskazywano, iż stwierdzenia o anulowaniu aliansu polsko-rumuńskiego i ewentualnym rumuńsko-sowieckim porozumieniu w kwestii Besarabii są wyrazem jedynie „osobistych poglądów” tureckiego ministra, które nie znajdują odzwierciedlenia w moskiewskich rokowaniach Patka z Litwinowem, tym bardziej że został przez nich niemal uzgodniony artykuł III paktu o nieagresji mówiący, iż „zobowiązania [stron - HW] wymienione w artykule pierwszym i drugim nie mogą w żadnym wypadku ograniczać, lub zmodyfikować [ich - HW] praw i zobowiązań międzynarodowych wynikających z układów zawartych uprzednio". Przewidywano, iż będą podejmowane przez wrogów Polski i Rumunii starania zmierzające do osłabienia łączących je więzów. Dlatego oba państwa, poprzez

34 Pismo Ghiki do poselstwa w Warszawie z 28 XI 1931, Behind..., s. 43; telegram Cesianu do MSZ z 9 XII 1931, ibidem; telegram Zaleskiego do Bukaresztu z 2 XII 1931, nr 132, HIA. Rumunia. Ks. szyf., nr 5, p. 2, f. 2; telegram Szembeka do MSZ z 4 XII 1931, nr 135, ibidem. 
solidarność i bliską współpracę w sprawach paktu, powinny dążyć do wzmocnienia tych więzów „zarówno we wzajemnych stosunkach i opinii międzynarodowej”35.

Ghica nie wydawał się do tego przekonany. $Z$ jego polecenia poseł Bilciurescu miał przedstawić ambasadorowi Larocheowi swoje „osobiste obawy, podzielane przez wielu Rumunów” dotyczące skutków działań Sowietów na rzecz paktów o nieagresji. Zdaniem posła uwidoczniły się one w osłabieniu frontu polsko-rumuńskiego, a tym samym systemu politycznego wspieranego przez Francuzów w tej części Europy. W przyszłości w przypadku osobnego podpisania paktów przez Polskę i Rumunię ich położenie uległoby dalszej degradacji. Nieuchronne byłoby również zmniejszenie znaczenia Francji. Czy zatem Paryż chciałby takiej ewolucji własnego położenia i swoich aliantek? - pytał Bilciurescu. Quai d’Orsay obcy był wszakże taki punkt widzenia. Berthelot stwierdził wobec Cesianu, iż akceptuje zawarcie paktu rumuńsko-sowieckiego z zastrzeżeniem, iż kwestia Besarabii nie zostanie zupełnie poruszona w rokowaniach. Do enuncjacji Rüştü Arasa Sekretarz Generalny francuskiego MSZ nie przywiązywał szczególnej uwagi, uznając ją podobnie jak Zaleski za „Zwykłą osobistą opinię" tureckiego ministra ${ }^{36}$.

Zamieszanie związane ze wspomnianą „opinią”, wyrażoną - jak się okazało - bez żadnego upoważnienia ze strony sowieckiej, nie zahamowało rumuńskich sondaży. Prowadzono je nadal w Ankarze oraz w Warszawie i Rydze. Można sądzić, iż z Palatul Sturdza wysyłano nieprecyzyjne instrukcje. W stolicy Turcji bowiem reprezentant Rumunii starał się uzyskać informacje o stanowisku ZSRR w sprawie ustanowienia oficjalnych stosunków dyplomatycznych. W Warszawie i Rydze miejscowi przedstawiciele rumuńscy indagowali swoich sowieckich interlokutorów w sprawie rokowań o nieagresji. 6 grudnia ambasador sowiecki w Turcji Jakow Suric przekazał posłowi rumuńskiemu Carpowi, iż rząd sowiecki jest skłonny przystąpić do negocjacji z Rumunią w sprawie „normalizacji stosunków między obu krajami”, a kwestię besarabską jako nieprzedstawiającą żadnej pilności pozostawia otwartą. Rumuni zapewne, aby się nie kompromitować, przekazali Szembekowi zmodyfikowaną treść depeszy, iż Rosjanie wyrazili gotowość zawarcia „paktu o nieagresji z pominięciem otwartej sprawy Besarabii" ${ }^{37}$.

Pozostawała jeszcze kwestia ustalenia miejsca rokowań i kandydatur głównych negocjatorów. Ze względu na przyjazny dla siebie grunt i utrudnienia, jakie musia-

35 Telegramy Szembeka do MSZ z 4 XII (nr 135), 5 XII (nr 136, stąd cytaty) 1931, ibidem; telegram posła sowieckiego w Ankarze, Jakowa Surica z 2 XII 1931, [w:] Sovetsko-rumynskie otnošeniâ. Dokumenty i materialy 1917-1934, t. 1, red. A. A. Avdeev i in., Moskva 2000 (dalej: SRO), s. 312-313; raport Patka do MSZ z 1 XII 1931, DMHSPR, t. V, s. 573-574 (to samo PDD 1931..., s. 735-736); G. Gafencu, op. cit., s. 287; L. Pădureac, Relaţiile româno-sovietice 1917-1934, Chişinău 2003, s. 114; Â. M. Kopanskij, I. Ė. Levit, op. cit., s. 78.

36 Telegram Cesianu do MSZ z 9 XII 1931, nr 892, Behind..., s. 46 (pierwszy cytat); telegram Szembeka do MSZ z 7 XII 1931, HIA. Rumunia. Ks. szyf., nr 5, p. 2, f. 2; G. Gafencu, op. cit., s. 287.

37 Telegram posła sowieckiego w Ankarze, J. Surica z 2 XII 1931, SRO, s. 312-313; list Litwinowa do Stalina z 5 XII 1931, ibidem, s. 313-314; telegram Carpa do MSZ z 6 XII 1931, ibidem, s. 314; telegram Szembeka do MSZ z 7 XII 1931, HIA. Rumunia. Ks. szyf., nr 5, p. 2, f. 2; Â. M. Kopanskij, I. È. Levit, op. cit., s. 79-80. 
łyby zaistnieć w bezpośrednich kontaktach polsko-rumuńskich, Rosjanie opowiadali się za Ankarą jako miejscem rokowań. Obsadzili już nawet stanowisko swojego negocjatora, którym miał być Suric. W zgodnej opinii Rumunów oraz Polaków i Francuzów naciskających na możliwie szybkie podjęcie rozmów, najlepszym dla nich miejscem byłaby Warszawa, gdzie istniałyby możliwości polsko-rumuńskiego współdziałania i lepsze połączenia komunikacyjne w porównaniu z Ankarą. Jednakże stolicę RP odrzucali dyplomaci sowieccy, twierdząc, iż pertraktacje toczyłyby się tam pod kontrolą Polski. Wobec tych rozbieżności polskie MSZ zaproponowało Rumunom Moskwę. Argumentowano, iż w stolicy ZSRR partnerem w negocjacjach byłby Litwinow, który wykazywał się większą elastycznością niż inni sowieccy dyplomaci za granicą; można byłoby wykorzystać duże doświadczenie Patka i jego znajomość terenu; poza tym negocjacje w Moskwie miały prowadzić Finlandia, Estonia i Łotwa, co stworzyłoby „wspólny front i podobieństwo do sytuacji z paktu Litwinowa”. Kandydatura Moskwy odpowiadała NKID. Byli jej natomiast przeciwni Rumuni. Ghica co prawda podnosił trudności techniczne, szczególnie brak rumuńskiego przedstawicielstwa w Moskwie oraz działania sowieckie tajnych służb, na które narażony byłby rumuński negocjator (podsłuch, kradzież szyfru, szpiegowanie), w istocie jednak obawiał się własnej opinii publicznej, „w ogóle” zdaniem Szembeka niechętnej pertraktacjom $\mathrm{z}$ Sowietami, tym bardziej w ich stolicy ${ }^{38}$.

Opóźnienie rokowań wywołało coraz większe zniecierpliwienie Francji ${ }^{39}$ i Polski. Quai d'Orsay zależało na jak najszybszym podpisaniu układu francusko-sowieckiego (skorelowanego jak wiadomo z zawarciem paktu polsko-sowieckiego, co z kolei uzależnione było od finalizacji paktu Moskwa-Bukareszt) w celu polepszenia położenia III Republiki względem Niemiec. Polacy informowali o podjęciu negocjacji przez Estonię i Łotwę, podkreślając, że ich własne negocjacje posuwają się naprzód i oferując, podobnie jak Francuzi, pomoc techniczną, czyli gościnę w pol-

38 Telegram Surica do Litwinowa z 2 XII 1931, SRO, s. 312-313; list Litwinowa do Stalina z 5 XII 1931, ibidem, s. 313-314; telegram Carpa do MSZ z 6 XII 1931, ibidem, s. 314; telegramy Schaetzela do poselstwa w Bukareszcie z 8 XII (nr 137), 10 XII (nr 138), 12 XII (nr 139), 13 XII (nr 141) 1931, HIA. Rumunia. Ks. szyf., nr 5, p. 2, f. 2; telegramy Szembeka z 7 XII (nr 138), 11 XII (nr 140), 15 XII (nr 142), 18 XII (nr 143) 1931, ibidem; telegram Zaleskiego do poselstwa w Bukareszcie z 16 XII 1931 (nr 142a, stąd cytat), ibidem; telegram Cesianu do MSZ z 9 XII 1931, Behind..., s. 46; raport Bilciurescu do Ghiki z 10 XII 1931, ibidem, s. 47-48; telegram Ghiki do poselstwa w Ankarze z 11 XII 1931, ibidem, s. 45-46; relacja z rozmowy Ghiki z ambasadorem francuskim Puaux z 18 XII 1931, ibidem, s. 49-51; telegram Bilciurescu do Ghiki z 20 XII 1931, ibidem, s. 51; G. Gafencu, op. cit., s. 288; deklaracje złożone przez pana D. Ghikę - ministra spraw zagranicznych, przedstawicielom prasy rumuńskiej 14 stycznia [1932 - HW] dotyczące konferencji reparacyjnej, Konferencji Rozbrojeniowej, wizyty w Warszawie i rumuńsko-sowieckich negocjacji w Rydze. AMAE. 71/1920-1944 România. Vol. 2, k.7 -11.

39 Minister Ghica winą za opóźnienie obarczył w rozmowie $\mathrm{z}$ ambasadorem francuskim Puaux dyplomację polską, skarżąc się m.in. na niedostarczenie przez Polaków do Bukaresztu projektu paktu o nieagresji, na podstawie którego Patek prowadził negocjacje w Moskwie oraz na fakt, że Warszawa nie przykłada dostatecznej wagi do zabiegów Sowietów zmierzających do rozdzielenia Polski i Rumunii. Należy stwierdzić, iż w świetle przeprowadzonych badań twierdzenia rumuńskiego ministra jawią się jako odległe od prawdy. Relacja z rozmowy Ghiki z ambasadorem francuskim Puaux z 18 XII 1931, Behind..., s. 49-51. 
skim poselstwie w Moskwie. Minister Zaleski uważał spieranie się z rządem sowieckim o miejsce rokowań za sprawę drugorzędną. Według niego ustępstwo Rumunii w tej kwestii mogło zostać zrekompensowane koncesjami sowieckimi w późniejszych pertraktacjach. Dla szefa polskiej dyplomacji było istotne, aby wreszcie w tej kwestii Bukareszt podjął decyzję. Zaleski stwierdził, iż nie będzie dalej forsował kandydatury Moskwy wbrew postrzeganiu przez Ghikę rumuńskiego interesu politycznego. Tymczasem Palatul Sturdza wystąpił z kandydaturą Rygi, którą zresztą już wcześniej obie strony traktowały jako alternatywę Ankary bądź Warszawy. Rząd sowiecki nie bez pewnych oporów zgodził się na stolicę Łotwy i poprosił Rumunię o podjęcie decyzji w sprawie terminu. Na polecenie Ghiki 31 grudnia 1931 r. poseł Carp poinformował Surica, iż negocjacje dotyczące rumuńsko-sowieckiego paktu o nieagresji rozpoczną się 5 stycznia, a prowadzić je będzie ad referendum Mihai Sturdza - rumuński chargé w stolicy Łotwy ${ }^{40}$.

Dyplomaci polscy w miarę zbliżania się terminu negocjacji rumuńsko-sowieckich interesowali się także projektem paktu, jaki Bukareszt zamierzał przedstawić Rosjanom. Na Wierzbowej - jak się wydaje - rumuński projekt z 25 sierpnia oceniano jako mało realną podstawę negocjacji. Stąd też Szembek indagował Bukareszt na temat nowego projektu, konstatując tu zupełny brak zaawansowania i informując Warszawę o prośbach Ghiki o udostępnienie tekstu paktu będącego przedmiotem negocjacji polsko-sowieckich. Po uzgodnieniu przez Patka z Rosjanami większości artykułów polsko-sowieckiego paktu o nieagresji, Zaleski poczuł się w obowiązku zasugerowania Rumunom, aby w swoim projekcie paktu utrzymali jako punkt wyjścia (preambuła) pakt Brianda-Kelloga, równoczesne wprowadzenie w życie paktów polsko-sowieckiego i rumuńsko-sowieckiego oraz jednakowy czas ich obowiązywania. Szef polskiej dyplomacji poinformował jeszcze Bukareszt, iż w artykule VII paktu uzgodniono, iż jego wymówienie może nastąpić na sześć miesięcy (a nie na trzy, jak było w projekcie z 23 sierpnia) przed upływem ważności. Rumuni 23 grudnia dostarczyli w końcu Szembekowi swój projekt paktu. W ocenie posła był on zgodny w „głównych zasadach” ze szkicem paktu polsko-sowieckiego ${ }^{41}$.

Rozmowy rumuńsko-sowieckie rozpoczęły się w Rydze dzień później niż zakładany termin, tj. 6 stycznia 1932 r., na co zapewne miało wpływ oczekiwanie M. Sturdzy na ostatnie instrukcje z kraju i związana z tym „dyplomatyczna choroba”. Na naradzie z udziałem Karola II, premiera Iorgi oraz ministra Ghiki ustalono, iż

40 Telegramy Szembeka z 7 XII (nr 138), 15 XII (nr 142), 18 XII (nr 143), 23 XII (nr 145) 1931, HIA. Rumunia. Ks. szyf., nr 5, p. 2, f. 2; telegramy Schaetzela do poselstwa w Bukareszcie z 17 XII (nr 144), 21 XII (nr 143), 24 XII (nr 151), 31 XII (nr 152) 1931, ibidem; telegramy Zaleskiego do poselstwa w Bukareszcie z 16 XII (nr 142a), 20 XII (nr 146) 1931, ibidem; relacja z rozmowy Ghiki z ambasadorem francuskim Puaux z 18 XII 1931, Behind..., s. 49-51; telegram Carpa do MSZ z 30 XII 1931, ibidem, s. 53; telegram Ghiki do Carpa z 31 XII 1931, ibidem, s. 54-56; telegram Surica do LKSZ z 26 XII 1931, SRO, s. 316-317; L. Pădureac, op. cit., s. 115; M. I. Mel'tûhov, op. cit., s. 159; zob. G. Gafencu, op. cit., s. 288.

41 Telegramy Szembeka z 4 XII (nr 135), 7 XII (nr 138), 23 XII (nr 145) 1931, HIA. Rumunia. Ks. szyf., nr 5, p. 2, f. 2; telegram Zaleskiego do poselstwa w Bukareszcie z 20 XII 1931 (nr 146), ibidem. 
rumuński negocjator winien dążyć do wprowadzenia do tekstu paktu o nieagresji takiej formuły, która niosłaby ze sobą uznanie przez ZSRR Besarabii za terytorium Rumunii. Szef bukareszteńskiego MSZ nie ukrywał swego braku entuzjazmu dla negocjacji, twierdząc, że pakt o nieagresji nie przyniesie Rumunii większych gwarancji od tych, które daje Protokół Litwinowa, jednakże Bukareszt zmuszony jest je podjąć na skutek nacisku Francji i Polski42. Mało optymistyczny ton przebijał nawet $\mathrm{w}$ prasowych enuncjacjach rumuńskiego ministra przebywającego $\mathrm{w}$ dniach 8-10 stycznia 1932 r. z wizytą w Warszawie, mimo iż rozmowy w Rydze były dopiero w początkowej fazie ${ }^{43}$.

Pierwsze spotkanie z sowieckim negocjatorem Borisem Stomoniakowem odbyło się w poselstwie ZSRR. Doszło wówczas do wymiany projektów paktów oraz ustalenia wahadłowego toku pertraktacji w poselstwach obu krajów. 7 i 11 stycznia miały miejsce dwa kolejne spotkania Sturdzy i Stomoniakowa. Sowiecki dyplomata zarzucał Rumunom, iż w swoim projekcie dążą nie tylko do zabezpieczenia się przed napaścią ze strony ZSRR, ale też chcą doprowadzić poprzez artykuł I, ustęp 2 (potwierdzenie „całości i nietykalności terytorium, znajdującego się obecnie pod suwerenną władzą drugiej umawiającej się strony") ${ }^{44}$ do

42 Instrukcja Ghiki dla Sturdzy z 31 XII 1931, SRO, s. 319-322; raport Ghiki dla rządu z 5 I 1932, ibidem, s. 322-325; Dziennik B. S. Stomoniakowa - pełnomocnika ZSRR do rozmów z Rumunią o pakt o nieagresji (dalej: Dziennik B. S. Stomoniakowa), ibidem, s. 326-327; telegram Ghiki do poselstwa w Paryżu z 6 I 1932, Behind..., s. 62; M. Sturdza, România şi sfârşitul Europei. Amintiri din ţara pierdută, Bucureşti 2004, s. 69; N. Iorga, Memorii. Incercarea guvernării peste partide (1931-2), vol. VI, București 1939, s. 274; Â. M. Kopanskij, I. Ė. Levit, op. cit., s. 80; L. Pădureac, op. cit., s. 115-116; zob. też F. Dessberg, La Roumanie, s. 69; M. I. Mel'tûhov, op. cit., s. 159.

43 Jednolity front polsko-rumuński i wyjazd min. Patka do Moskwy, „Ilustrowany Kurier Codzienny” 12 I 1932, s. 2; E. Jēkabsons, Stosunki polsko-rumuńskie w oczach dyplomacji łotewskiej w latach 1931-1939 (wyciąg ze sprawozdania posła Łotwy w Polsce O. Grosvaldsa do MSZ z 11 IV 1932 r.), [w:] Stosunki polsko-rumuńskie w XX wieku. Wybrane zagadnienia, red. M. Patelski, M. Białokur, Toruń-Opole 2010, s. 93; deklaracje złożone przez pana D. Ghikę - ministra spraw zagranicznych, przedstawicielom prasy rumuńskiej 14 stycznia [1932 r. - HW] dotyczące konferencji reparacyjnej, Konferencji Rozbrojeniowej, wizyty w Warszawie i rumuńsko-sowieckich negocjacji w Rydze (dalej: deklaracje złożone przez Ghikę). AMAE. 71/1920-1944 România. Vol. 2, k. 7; zob. też D. Ghyka, op. cit., s. 304-307.

44 Projekt paktu o nieagresji między Rumunią a ZSRR z 29 grudnia 1931 r. Centralny Komitet Wykonawczy Związku Socjalistycznych Republik Radzieckich, z jednej strony i J. W. Król Rumunii, z drugiej strony, kierowani pragnieniem umocnienia politycznego położenia we Wschodniej Europie za pomocą bezpośrednich porozumień, a także podtrzymania i utrwalenia istniejącego między dwoma krajami stanu pokoju, utrwalonego Protokołem Moskiewskim z 9 lutego 1929 r. o przedterminowym wejściu w życie układu o wyrzeczeniu się wojny, podpisanego w Paryżu 27 sierpnia 1928 r., przekonani, że pokojowe uregulowanie międzynarodowych konfliktów jest najbardziej pewnym środkiem osiągnięcia postawionego celu i mocno przekonani, że żadne wcześniej przyjęte na siebie zobowiązania nie przeszkadzają pokojowemu rozwojowi ich stosunków wzajemnych i nie przeczą niniejszemu traktatowi, zdecydowali się zawrzeć traktat, mający na celu poszerzyć i uzupełnić wspomniany wyżej Protokół Moskiewski i Układ Paryski i wyznaczyli do tego swoimi pełnomocnymi przedstawicielami, którzy, po wymianie pełnomocnictw, uznanych za będące w odpowiedniej formie, zgodzili się na następujące postanowienia: 
uznania przez Związek Sowiecki aneksji Besarabii, na co ten ani pośrednio, ani bezpośrednio nie pójdzie. Stomoniakow uważał, iż jedynym kompromisowym rozwiązaniem tej sprawy byłby plebiscyt. Ze względu jednak na dobro negocjacji Moskwa gotowa byłaby pozostawić tę kwestię otwartą, tak jak to jest w preambule jej projektu (stwierdzenie o istnieniu „terytorialnego sporu między dwoma

Artykuł 1. Wysokie Umawiające się Strony, zaznaczając, że wyrzekają się wojny jako środka narodowej polityki w ich stosunkach wzajemnych, zobowiązują się wzajemnie nie przedsiębrać żadnych napaści lub agresywnych działań na lądzie, na morzu lub w powietrzu przeciwko drugiej Umawiającej się Stronie. Jako działania sprzeczne ze zobowiązaniami, przewidzianymi w poprzednim akapicie, będzie się uważać wszelkie akty gwałtu, zagrażające całości i nietykalności terytorium, znajdującego się obecnie pod suwerennością drugiej Umawiającej się Strony, a także jej politycznej niezależności, nawet jeśli podobny akt byłby dokonany bez wypowiedzenia wojny albo nie miał charakteru aktu wojennego.

Artykuł 2. Jeśli jedna z Wysokich Umawiających się Stron, mimo swego pokojowego nastawienia, stanie się obiektem ataku ze strony trzeciego państwa albo grupy trzecich państw, druga Umawiająca się Strona zobowiązuje się nie udzielać pomocy i poparcia państwu albo grupie państw-agresorów w ciągu całego czasu konfliktu. Na wypadek, jeśli jedna z Wysokich Umawiających się Stron dokona aktu przemocy w odniesieniu do trzeciego państwa, druga Umawiająca się Strona ma prawo wypowiedzieć niniejszy traktat bez uprzedniego zawiadomienia.

Artykuł 3. Międzynarodowe prawa i obowiązki, wynikające dla każdej z Wysokich Umawiających się Stron z porozumień, paktów, umów albo innych uzgodnień, zawartych do nabrania mocy obecnego Układu, zachowują swoje działanie; zobowiązania, zapisane w niniejszym traktacie, ich nie zmieniają i nie zawężają.

Artykuł 4. Obie Wysokie Umawiające się Strony, kierowane pragnieniem rozwiązywania i przerywania wyłącznie pokojowymi środkami wszelkich sporów i konfliktów, jakie mogłyby powstać między nimi, niezależnie od ich charakteru, zobowiązują się stosować odnośnie do wszystkich spornych spraw, których nie udałoby się im uregulować w porę, procedurę rozjemczą zgodnie z przepisami konwencji rozjemczej, zawartej równocześnie z niniejszym traktatem i będącej jego częścią składową. Tych przepisów nie stosuje się do sporów, wywołanych przez fakty, które zaistniały do podpisania obecnej Konwencji i przynależnych do przeszłości.

Artykuł 5. Wysokie Umawiające się Strony zgadzają się w tym, żeby innym rządom, podpisującym Protokół Moskiewski z 9 lutego 1929 r., a także Finlandii zostało zaproponowane zawarcie z ZSRR porozumienia, analogicznego do niniejszego traktatu.

Artykuł 6. Traktat niniejszy będzie ratyfikowany a wymiana dokumentów ratyfikacyjnych odbędzie się w... Wejdzie on w życie po 30 dniach od zawiadomienia Rumunii przez ZSRR, że analogiczne porozumienia między ZSRR z jednej strony i Estonią, Finlandią, Łotwą i Polską z drugiej strony, zostały ratyfikowane, a wymiana dokumentów ratyfikacyjnych została dokonana.

Artykuł 7. Terminu obowiązywania niniejszego traktatu - 3 lata. Jeśli żadna z Wysokich Umawiających się Stron nie wypowie go, skierowawszy uprzednio zawiadomienie co najmniej sześć miesięcy do upływu tego terminu, będzie on uważany za automatycznie przedłużony na nowy okres 2 lat i tak dalej do jego wypowiedzenia w terminie, przewidzianym wyżej.

Protokół podpisania

Wysokie Umawiające się Strony oświadczają, że artykuł 7 nie może być interpretowany w tym sensie, że zaprzestanie działania traktatu po upływie terminu albo na skutek wypowiedzenia może w jakikolwiek sposób anulować zobowiązania, wynikające z układu podpisanego 27 sierpnia $1928 \mathrm{r}$. w Paryżu, a także protokołu, podpisanego 9 lutego 1929 r. w Moskwie lub w jakikolwiek sposób wpłynąć na wyżej wymienione zobowiązania. SRO, s. 317-319. 
Umawiającymi się Stronami w sprawie Besarabii, który jest nieuregulowany") ${ }^{45}$ albo zawrzeć takie stwierdzenie w załączonym aneksie ${ }^{46}$.

W odpowiedzi Sturdza stwierdził, iż ustęp 2 artykułu I został wprowadzony jedynie, aby rozszerzyć sowieckie zobowiązanie nieagresji także na Besarabię; podkreślał, iż pakt nie miałby dla Bukaresztu absolutnie żadnej wartości, jeśli nie zostałoby w nim zafiksowane respektowanie obecnych granic Rumunii. Sturdza zadeklarował gotowość poszukiwania wraz ze Stomoniakowem takiej formuły, która realizowałaby ten cel. Przedstawiciel bukareszteńskiego MSZ wykluczył jakąkolwiek możliwość poruszania w negocjacjach sprawy besarabskiej. Przypomniał o obietnicy złożonej Patkowi przez Litwinowa 14 listopada ub.r., pozostawienia sprawy besarabskiej „na

45 Sowiecki projekt Traktatu o nieagresji między ZSRR i Rumunią [bez daty - WH]. Centralny Komitet Wykonawczy Związku Socjalistycznych Republik Radzieckich, Jego Królewska Mość, Król Rumunii, ożywieni wolą utrwalenia pokoju; mający mocne przekonanie, że ustanowienie pokojowych stosunków między Obiema Umawiającymi się Stronami odpowiada ich interesom; konstatując, że ustanowienie takich stosunków nie przynosi żadnego uszczerbku dla dotychczas istniejącego terytorialnego sporu między dwoma Umawiającymi się Stronami w sprawie Besarabii, który jest nie uregulowany przez niniejszy traktat; zważywszy, że sytuacja, o której wzmianka została zrobiona w poprzednim paragrafie [zdaniu - przyp. HW] również znalazła swój wyraz w podpisanym przez dwie Umawiające się Strony, Ogólnym Traktacie o Wyrzeczeniu się Wojny z 27 sierpnia 1928 i Protokole Moskiewskim z 9 lutego 1929; postanowili zawrzeć niniejszy traktat i naznaczyć w tym celu swoich pełnomocników, a mianowicie: Komitet Wykonawczy Związku Socjalistycznych Republik Radzieckich... Jego Królewska Mość, Król Rumunii... którzy, po zakomunikowaniu sobie swoich pełnomocnictw uznanych za dobre i w należnej formie, zgodzili się na następujące klauzule:

Artykuł I. Każda z Umawiających się Stron zobowiązuje się nigdy nie podejmować w stosunku do drugiej, samodzielnie lub w połączeniu z innymi mocarstwami, jakiejkolwiek agresji na ziemi, na morzu lub w powietrzu i w żadnym wypadku uciekać się do wojny przeciw drugiej stronie.

Artykuł II. W przypadku gdyby jedna z Umawiających się Stron stała się przedmiotem agresji ze strony trzeciego Państwa lub grupy trzecich państw, druga Strona zobowiązuje się przestrzegać neutralności podczas całego trwania konfliktu.

Artykuł III. Każda z Umawiających się Stron zobowiązuje się nie brać udziału w jakimkolwiek porozumieniu wrogim drugiej stronie lub pozostającym w sprzeczności prawnej lub faktycznej z niniejszym traktatem.

Artykuł IV. Każda z Umawiających się Stron zobowiązuje się nigdy nie pozwalać na swoim terytorium na pobyt lub działalność organizacji mających na celu zbrojną walkę przeciwko drugiej Stronie lub organizacji czy też osób uzurpujących sobie rolę rządu albo reprezentanta całości lub części jego terytorium.

Artykuł V. Traktat niniejszy będzie ratyfikowany. Dokumenty ratyfikacyjne będą wymienione w... Wejdzie on w życie w dniu tej wymiany.

Artykuł VI. Traktat niniejszy jest zawarty na okres trzech lat. Jeżeli jedna z Umawiających się Stron nie wypowie go sześć miesięcy przed końcem trzyletniego okresu, to ważność traktatu automatycznie będzie przedłużona na nowy dwuletni okres.

Sporządzony w dwóch kopiach w ... dnia..., Behind..., s. 64-66.

46 Telegram Stomoniakowa do Litwinowa z 6 I 1932, Dokumenty vnešnej politiki SSSR. T. 15: 1 ânvarâ-31 dekabrâ 1932 g., red. G. K. Deev i in., Moskva 1969 (dalej: DVP, t. XV), s. 14; Dziennik B. S. Stomoniakowa, SRO, s. 328-329; notatka Sturdzy do Ghiki z 7 I 1932, SRO, s. 342; telegram Sturdzy do MSZ z 13 I 1932, Behind..., s. 73-74; M. Sturdza, op. cit., s. 70; deklaracje złożone przez Ghikę, AMAE. 71/1920-1944 România. Vol. 2, k. 10-11; zob. Â. M. Kopanskij, I. Ė. Levit, op. cit., s. 81-82. 
boku”, przywołując precedens Protokołu Moskiewskiego, w którym nie była ona wzmiankowana ${ }^{47}$.

Replikując Stomoniakow wskazał na różnicę między paktem o nieagresji a wielostronnym układem paryskim, który mówił tylko o zakazie wojny jako narzędzia polityki narodowej, podczas gdy ten pierwszy jest jego rozwinięciem i zawiera szereg bardziej konkretnych postanowień. Dyplomata sowiecki stwierdził, iż niewzmiankowanie w pakcie sprawy besarabskiej mogłoby zostać interpretowane jak zrzeczenie się praw ZSRR do tej prowincji, co w NKID uważano za wykluczone. Stomoniakow przypomniał, że Litwinow przed podpisaniem Protokołu Moskiewskiego w jednostronnej deklaracji wygłoszonej przed przedstawicielami przyszłych sygnatariuszy, stwierdził, iż podpisanie tego dokumentu pozostawia nadal nierozwiązany problem besarabski. W odniesieniu do obietnicy Litwinowa danej Patkowi, wskazał, iż obecne negocjacje odbywają się nie na podstawie ich rozmowy, ale na bazie propozycji rumuńskiego rządu, skierowanej pod adresem ZSRR i przezeń przyjętej, gdzie jednakowoż nie było żadnych tego typu ustalen' ${ }^{48}$.

Przedstawiciel Rumunii nie chciał podpisywać ze Stomoniakowem żadnych oficjalnych dokumentów ani przyjmować odeń not, obawiając się wzmiankowania w nich kwestii besarabskiej jako sporu istniejącego między ZSRR i Rumunią i zdyskontowania przez Moskwę tego faktu propagandowo. Chciał także uniknąć zarzutu nieustępliwości i rozbicia rokowań, dlatego też zaproponował Stomoniakowowi pozostawienie dalszego „badania preambuły” na koniec rozmów i przejście do dyskusji nad artykułami paktu. Sowiecki dyplomata zgodził się na zaakceptowanie tej formuły, pod warunkiem zastąpienia słów „badanie preambuły” przez „badanie istniejących sporów”49.

Strona rumuńska zdezorientowana dotychczasowymi rozmowami w Rydze wystąpiła wobec Polski z prośbą o przedstawienie przez Patka w Moskwie démarche w sprawie wyjaśnienia rzeczywistych intencji sowieckich. Dyplomaci rumuńscy przypominali, że Bukareszt poszedł na negocjacje z Sowietami pod warunkiem pozostawienia sprawy Besarabii „na boku” i że takie obietnice otrzymał ze strony NKID. Podkreślano, iż Rumunia nie może pozwolić na dyskusję w Rydze kwestii Besarabii i przez to sama kwestionować swoje suwerenne prawa, a sojusznicy polski i francuski nie mogą od niej oczekiwać ustępstw w tej materii. Zapowiadano, że jeśli ZSRR nie zmieni swojego stanowiska i nie będzie negocjować zgodnie z wcześniejszymi zapewnieniami, wówczas pertraktacje zostaną zerwane ${ }^{50}$.

47 Dziennik B. S. Stomoniakowa, SRO, s. 329; pismo Sturdzy do Ghiki z 6 I 1932, Behind..., s. 63-64; telegram Sturdzy do MSZ z 11 I 1932, ibidem, s. 71-72; telegram Stomoniakowa do Litwinowa z 7 I 1932, SRO, s. 340; notatka Sturdzy do Ghiki z 7 I 1932, SRO, s. 342-343; telegram Sturdzy do MSZ z 13 I 1932, Behind..., s. 73-74; M. Sturdza, op. cit., s. 70; L. Pădureac, op. cit., s. 116.

48 Dziennik B. S. Stomoniakowa, SRO, s. 335-337; notatka Sturdzy do Ghiki z 7 I 1932, ibidem, s. 342-344; telegram Szembeka do MSZ z 13 I 1932, nr 9, HIA. Rumunia. Ks. szyf., nr 6, p. 2, f. 3; zob. telegram Litwinowa do Stomoniakowa z 12 I 1932, SRO, s. 346-347.

49 Telegram Sturdzy do MSZ z 11 I 1932, Behind..., s. 71-72 (stąd cytaty); telegram Szembeka do MSZ z 13 I 1932, nr 9, HIA. Rumunia. Ks. szyf., nr 6, p. 2, f. 3; M. Sturdza, op. cit., s. 70.

50 Memorandum Ariona do Ghiki z 12 I 1932, Behind..., s. 72-73; telegram Szembeka do MSZ z 13 I 1932, nr 9, HIA. Rumunia. Ks. szyf., nr 6, p. 2, f. 3. 
Szembek usiłował uspokajać Rumunów, twierdząc, iż postawa Stomoniakowa może być tylko taktyką dyplomatyczną służącą sondowaniu partnera i zmierzającą do uzyskania maksymalnych korzyści. W ocenie polskiego posła, strona sowiecka po tym „gwałtownym debiucie” miała stać się bardziej umiarkowana w kolejnej fazie rozmów. Zaleski natomiast potwierdzał podjęcie przez Patka stosownych kroków w Moskwie i doradzał Rumunom kontynuowanie negocjacji celem uwidaczniania swojej „dobrej woli”. Ponowił też zapewnienie o niewprowadzaniu w życie przez Polskę paktu o nieagresji z Moskwą bez Rumunii ${ }^{51}$.

Niedługo potem Patek spotkał się z Litwinowem. Przypomniał mu o rozmowie z 14 listopada i uzyskał potwierdzenie jej treści. Ludowy komisarz poinformował go, iż Stomoniakow otrzymał instrukcję, by w pakcie nie wspominać o sprawie Besarabii, lecz jedynie ogólnikowo o sporze terytorialnym. Na przywołanie przez posła RP sposobu załatwienia sprawy w protokole moskiewskim Litwinow odpowiedział, iż pakt o nieagresji ma inny charakter i stąd konieczność nadania temu „formy bardziej konkretnej”. Szef NKID zaznaczył jeszcze potrzebę „specjalnej ostrożności” strony sowieckiej w tej kwestii, przypominając „opaczną interpretację" paktu przez prasę rumuńską; jak można sądzić Litwinow miał tu na myśli artykuły zapowiadające oficjalne uznanie w pakcie przynależności Besarabii do Rumunii. Ludowy komisarz zakomunikował też Patkowi o nakazaniu Stomoniakowowi omawiania ze Sturdzą poszczególnych artykułów i dopiero potem powrotu do uzgadniania preambuły. Należy zaznaczyć, iż Litwinow nie był wobec polskiego posła do końca szczery. W przesłanej bowiem do Rygi 12 stycznia instrukcji polecał sowieckiemu negocjatorowi, aby nie pozostawiał Sturdzy złudzeń odnośnie do zgody Rosjan na pominięcie w pakcie sprawy Besarabii i wskazał, że już sama zgoda Moskwy na układ o nieagresji jest wielkim ustępstwem wobec Bukaresztu, ponieważ po jego zawarciu dalej będzie kontynuowana „faktycznie bezprawna okupacja Besarabii”; stąd też i nie można żądać od ZSRR rezygnacji ze wzmiankowania w pakcie o pozostawieniu sprawy otwartej ${ }^{52}$.

Dyskusja obu negocjatorów nad poszczególnymi artykułami paktu rozpoczęła się 13 stycznia. Dość szybko uzgodnili oni ustęp 1 artykułu I, stanowiący połączenie odnośnych części z projektów rumuńskiego i sowieckiego. W akapicie tym konstatowano wyrzeczenie się przez obie strony wojny jako narzędzia polityki narodowej w stosunkach wzajemnych i zobowiązywano się do niepodejmowania przeciwko drugiej stronie, samodzielnie lub w połączeniu z innymi państwami, jakiejkolwiek napaści na lądzie, morzu i w powietrzu i w żadnym wypadku nieprzystępowania do wojny przeciwko kontrahentowi. Należy dodać, iż ustęp ten Sturdza zaakceptował

51 Telegram Ghiki do Sturdzy z 12 I 1932, Behind..., s. 72; telegram Szembeka do MSZ z 13 I 1932, nr 9, HIA. Rumunia. Ks. szyf., nr 6, p. 2, f. 3 (stąd cytaty); telegram Zaleskiego do poselstwa w Bukareszcie z 14 I 1932, nr 5, ibidem.

52 Telegram Zaleskiego do poselstwa w Bukareszcie z 17 I 1932, nr 7 (dwa pierwsze cytaty), ibidem; telegram Litwinowa do Stomoniakowa z 12 I 1932, SRO, s. 346-347; telegram Sturdzy do MSZ z 14 I 1932, Behind..., s. 74-75; M. Sturdza, op. cit., s. 70; L. Pădureac, op. cit., s. 116. 
pod warunkiem dopełnienia go akapitem $2 \mathrm{z}$ artykułu I projektu rumuńskiego ${ }^{53}$, na co jednak nie zgodził Stomoniakow.

Obaj negocjatorzy doszli też do porozumienia odnośnie do artykułu II, który stanowił połączenie artykułu II projektu sowieckiego z częścią tego samego artykułu z projektu rumuńskiego. Artykuł ten stwierdzał w ustępie 1, iż jeśli w razie wojny jeden $\mathrm{z}$ kontrahentów ulegnie napaści ze strony państwa trzeciego albo grupy trzecich państw, drugi kontrahent zobowiązuje się zachowywać neutralność podczas całego trwania konfliktu. Akapit 2 będący powieleniem ustępu 2 projektu rumuńskiego zapowiadał możliwość wypowiedzenia paktu bez uprzedniego zawiadomienia, jeśli jedna ze stron przedsięwzięłaby agresję przeciwko państwu trzeciemu.

W odpowiedzi na propozycje Sturdzy przyjęcia artykułów V i VI projektu rumuńskiego, dotyczących skorelowania ze sobą zawarcia, ratyfikacji i wejścia w życie paktów Rumunii i pozostałych limitrofów z ZSRR, Stomoniakow wystąpił $\mathrm{z}$ własną kontrpropozycją przyjęcia artykułu V sowieckiego projektu traktującego o ratyfikacji i wejściu w życie paktu. Inicjatywa ta, jak się wydaje, znalazła akceptację rumuńskiego negocjatora, choć nie zostało to potwierdzone expressis verbis. Jednakże w toku dalszych negocjacji do sprawy tej już nie wracano.

Delegaci wyrazili zgodę na tekst ostatniego artykułu paktu, który odpowiadał analogicznym artykułom z projektów sowieckiego (niemal dosłownie) i rumuńskiego. Określał on czas trwania paktu na trzy lata i możliwość jego automatycznego przedłużenia na dwa kolejne, jeśli żadna ze stron nie wypowiedziałaby sześć miesięcy przed końcem jego obowiązywania.

Wydawać by się mogło, iż porozumienie osiągnięto w sprawie artykułu IV, w którym nastąpiło połączenie analogicznego artykułu projektu sowieckiego i uzupełnień delegata rumuńskiego ${ }^{54}$. Jednakże na spotkaniu negocjatorów 18 stycznia powrócono do dyskusji nad nim ${ }^{55}$ i ostatecznie zeń zrezygnowano na posiedzeniu 20 stycznia $^{56}$.

53 Akapit ów uznawał za sprzeczne ze zobowiązaniami z poprzedniego akapitu wszelkie akty gwałtu godzące w całość oraz w niezależność polityczną i nietykalność terytorium znajdującego się aktualnie po suwerenną władzą drugiej strony, nawet jeśli taki akt zostałby dokonany bez ogłoszenia wojny i nie będzie miał charakteru wojskowego działania. Protokół z 1 posiedzenia negocjacji o pakt o nieagresji z 13 I 1932 między ZSRR a Rumunią, SRO, s. 347-348; Projekt paktu nieagresji między Rumunią a ZSRR z 29 grudnia 1931, ibidem, s. 317-318.

54 Zobowiązywał on kontrahentów do niedopuszczania na swoim terytorium do pobytu lub działalności organizacji mających za cel zbrojną walkę przeciwko drugiej stronie, a także organizacji i osób pretendujących do roli rządu lub przedstawicielstwa całego albo części terytorium drugiej strony. Za sprawą Sturdzy został wprowadzony akapit zabraniający wszelkim organizacjom, istniejącym już na terenie jednego z państw, uprawiania prowokacji jakimikolwiek środkami lub wspierania politycznych zamieszek albo społecznych konfliktów na terenie drugiego. Protokół z 1 posiedzenia negocjacji o pakt o nieagresji między ZSRR a Rumunią, SRO, s. 348-349.

$55 \mathrm{~W}$ miejsce swoich poprzednich poprawek dyplomata rumuński proponował wprowadzenie passusu zakazującego wszelkim organizacjom istniejącym na terenie jednego z państw inspirowania i podtrzymywania zamieszek lub niepokojów na terytorium kontrahenta. Protokół nr 3 z posiedzenia negocjacji o pakt o nieagresji między ZSRR a Rumunią z 18 I 1932, SRO, s. 356-357.

56 Protokół nr 4 z posiedzenia negocjacji o pakt o nieagresji między ZSRR a Rumunią z 20 I 1932 r., SRO, s. 359-360. 
W toku prowadzonej wówczas dyskusji dyplomata sowiecki stwierdził, iż bez odnotowania zasadniczego stanowiska ZSRR w sprawie Besarabii i pominięcia słów: „integralność, nienaruszalność i suwerenność” nigdy nie podpisze on paktu o nieagresji z Rumunią. W tych okolicznościach prowadzenie rokowań jawiło się Sturdzy jako taktyczny błąd. Jednakże ze względu na postawę Paryża i Warszawy gotów był je kontynuować. Za ich nieśpiesznym kontynuowaniem był także Zaleski, który w tym czasie starał się koordynować rokowania Polski i pozostałych limitrofów z Moskwą, aby ograniczyć jej pole manewru dla zyskania od poszczególnych państw różnych ustępstw. Uważał on, że czynnikiem dopingującym nie powinien być nawet termin zbliżającej się Konferencji Rozbrojeniowej w Genewie, gdyż prowadzenie pertraktacji w sprawie paktów w czasie jej trwania nie osłabi tam pozycji krajów graniczących z Moskwą. Biorąc pod uwagę realia rumuńsko-sowieckich negocjacji, Zaleski w rozmowie z Bilciurescu zalecał Bukaresztowi odstąpienie na razie od dyskusji nad preambułą oraz ustępem 2 artykułu I i szukanie porozumienia odnośnie do pozostałych artykułów. Szef polskiego MSZ zakładał, iż jeśli nawet nie udałoby się znaleźć zadowalającej formuły traktatu, to kiedy wszystkie pakty (oprócz rumuńsko-sowieckiego) zostałyby wynegocjowane, można byłoby wywrzeć nacisk na Moskwę, grożąc ich niepodpisaniem, jeśli nie osiągnęłaby ona zgody także z Rumunią. Minister RP poinformował też rumuńskiego posła o kolejnej rozmowie Patka z Litwinowem, w czasie której ten drugi stwierdził, iż jego zgoda na pomijanie milczeniem kwestii Besarabii nie miała charakteru formalnej obietnicy i że zamiast wzmianki o tej prowincji w tekście paktu, mógłby umieścić ją w oddzielnym akcie dyplomatycznym lub uczynić przedmiotem wymiany not. Propozycja komisarza nie znalazła uznania Bilciurescu, natomiast Zaleski wyraził przekonanie, iż ostatecznie Litwinow zadowoli się w tej kwestii własną jednostronną deklaracją, która zostanie przedstawiona po podpisaniu paktu, tak jak to miało miejsce przy okazji finalizacji protokołu moskiewskiego ${ }^{57}$.

W czasie wymiany zdań ze Stomoniakowem, która miała miejsce 15 stycznia, Sturdza zaproponował zdefiniowanie w pakcie aktów sprzecznych ze zobowiązaniem nieagresji, które zawierałoby odniesienia do nietykalności i integralności terytorialnej oraz narodowej suwerenności. Stomoniakow odrzucił tę formułę, deklarując jednocześnie gotowość poszukiwania wraz z Rumunami takiego sformułowania, które dając Rumunii „materialną satysfakcję w sprawie nieagresji” byłoby do przyjęcia dla rządu sowieckiego. W przekonaniu rumuńskiego negocjatora tylko

57 Telegram Sturdzy do MSZ z 14 I 1932, Behind..., s. 74-75; telegram Bilciurescu do MSZ z 15 I 1932, ibidem, s. 76; telegram Bilciurescu do Ghiki z 16 I 1932, ibidem, s. 79-80; L. Pădureac, op. cit., s. 116; F. Dessberg, La Roumanie, s. 69; D. Hrenciuc, România şi Polonia 1932-1939. Relaţii politice şi diplomatice, Iaşi 2005, s. 23. Warto dodać, iż Zaleski w rozmowie z Bilciurescu, przeprowadzonej 15 stycznia „bez zamiaru jakiegokolwiek nacisku”, doradzał Rumunom rezygnację w pakcie z formuły suwerenności terytorium w zamian za wyrzeczenie się przez ZSRR zastrzeżeń dotyczących Besarabii. Poseł rumuński uznał taki kompromis za niekorzystny dla swego kraju. W jego przekonaniu, ekwiwalentem Moskwy za ustępstwo Bukaresztu powinno być formalne uznanie przez nią przynależności Besarabii do Rumunii. Telegram Bilciurescu do MSZ z 15 I 1932, ibidem, s. 76. 
jednoznaczna gwarancja całości i nietykalności terytorium mogłaby doprowadzić do zawarcia paktu o nieagresji. Natomiast poszukiwanie formuły niezawierającej wspomnianych pojęć byłoby w jego przekonaniu zbyteczne i nie do przyjęcia dla rządu w Bukareszcie. Sturdza uważał, iż sytuacja dojrzała do zerwania negocjacji. Stąd też krytycznie oceniał on prośby o ich nierozbijanie formułowane przez polskich dyplomatów, którzy argumentowali, iż Ludowy Komisariat doszedł już do ostatecznej granicy bluffu i odtąd przyjmie postawę bardziej kompromisową ${ }^{58}$.

Sugestie Sturdzy o możliwości zerwania rokowań zostały przyjęte przez Ghikę z niepokojem. W jego przekonaniu dla Rumunii było bardziej korzystne, aby do zerwania doszło ze strony Sowietów. Sprawa ta mogłaby zostać zdyskontowana przez dyplomację królewską na zbliżającej się Konferencji Rozbrojeniowej w Genewie. Szef dyplomacji bukareszteńskiej, biorąc pod uwagę życzenia polskiego sojusznika, który po raz kolejny deklarował zasadę współzależności wejścia w życie paktów rumuńskiego i polskiego z ZSRR, godził się na kontynuowanie pertraktacji, nawet jeśli byłyby prowadzone podczas Konferencji Rozbrojeniowej w Genewie. Liczył się wówczas Ghica z odstąpieniem od zapisów w pakcie o „całości, nietykalności i suwerenności” i zastąpienia ich dla oznaczenia granicy sowiecko-rumuńskiej konkretnym pojęciem geograficznym w postaci Dniestru, co miało już swój precedens w Statucie Tyraspolskim ${ }^{59}$. Rozważania szefa rumuńskiej dyplomacji napotkały opór Sturdzy. Uznał on, iż z propozycją taką należy wystąpić tylko po niepowodzeniu wynegocjowania formuły zawierającej pojęcia integralności i nienaruszalności (pojęcie suwerenności uważał za niemożliwe do przeforsowania). A wtedy w zamian za przyjęcie Dniestru jako linii rozgraniczenia, respektowanej przez Moskwę, należałoby jej zaproponować wyrzeczenie się w pakcie jakichkolwiek zastrzeżeń odnośnie do sprawy besarabskiej. Delegat rumuński przewidywał jako wielce prawdopodobną odmowę spełnienia przez Sowiety tego warunku, co miało doprowadzić do zerwania negocjacji z winy ZSRR ${ }^{60}$.

Kolejne posiedzenie obu negocjatorów mające miejsce 18 stycznia przyniosło uzgodnienie artykułu III. Stwierdzał on, iż żadne międzynarodowe zobowiązania, przyjęte wcześniej przez jednego z kontrahentów, nie zawierają przeszkód dla istnienia pokojowych stosunków $\mathrm{z}$ drugim i nie przeczą finalizowanemu paktowi; ponadto obaj partnerzy zgadzali się nie zawierać w przyszłości porozumień, przeczących faktycznie i de iure temu paktowi. Na tym samym posiedzeniu Sturdza zaproponował wprowadzenie do paktu artykułu konstatującego wierność stron międzynarodowym zobowiązaniom przyjętym do tego czasu przez siebie i stwierdzającego, że warunki paktu nie mogą ich ani zmienić, ani przynieść im uszczerbku.

58 Protokół z 2 posiedzenia negocjacji o pakt o nieagresji między ZSRR a Rumunią z 15 I 1932, SRO (stąd cytat) s. 350; telegram Sturdzy do MSZ z 16 I 1932, Behind..., s. 78-79.

59 Chodzi o „Przepisy o przedsięwzięciach i środkach, mających na celu zapobieganie i rozwiązywanie konfliktów, mogących powstać nad rzeką Dniestr”, SRO, s. 203-208.

60 Telegram Ghiki do Sturdzy z 15 I 1932, SRO, s. 351; telegram Sturdzy do MSZ z 16 I 1932, Behind..., s. 77-78. 
W dwa dni później na kolejnym posiedzeniu artykuł został uzupełniony passusem stwierdzającym, iż dawne zobowiązania nie zawierają żadnych elementów agresji ${ }^{61}$.

18 stycznia negocjator rumuński z własnej inicjatywy, a bez konsultacji z Bukaresztem wystąpił z propozycją ustalenia akapitu 2 artykułu I w następującym brzmieniu: „Jako akty sprzeczne ze zobowiązaniami przewidzianymi w poprzednim akapicie, będą uważane wszelkie akty przemocy przynoszące uszczerbek nietykalności terytorium, ograniczonemu Dniestrem i pozostałymi granicami, lądowymi, morskimi i powietrznymi, obu krajów, nawet jeśli podobny akt będzie przedsięwzięty bez wypowiedzenia wojny lub nie będzie miał charakteru działań wojennych". Propozycji Sturdzy towarzyszyło zastrzeżenie, iż nie nastąpi przy tym jakiekolwiek zmniejszenie ogólnej wartości paktu i że żaden element obcy podstawowemu celowi tego paktu nie zostanie wprowadzony do jakiejkolwiek jego części i ostatecznej redakcji.

Po konsultacji z Litwinowem, Stomoniakow odmówił w imieniu swego rządu zawarcia paktu bez wzmiankowania zastrzeżeń w kwestii besarabskiej, gdyż mogło to być odczytane jako bezpośrednie lub pośrednie uznanie przyłączenia Besarabii do Rumunii, które ZSRR uznawał za bezprawne. Sowiecki dyplomata stwierdził też, iż nie może przyjąć rumuńskiego definiowania aktów sprzecznych z paktem o nieagresji, tak jak nie może uznać obecnych granic Rumunii. Niejako w zamian sowiecki negocjator zaoferował własne brzmienie tego akapitu głoszące, iż za akty sprzeczne ze zobowiązaniami, przewidzianymi w poprzednim akapicie, będą uważane wszelkie próby każdej ze stron rozwiązywania drogą przemocy spornych kwestii terytorialnych lub innych istniejących między jedną a drugą stroną ${ }^{62}$.

W tej sytuacji Sturdza oświadczył, że sowiecka propozycja tworzy nową sytuację i że on uważa za bezużyteczne przedłużanie negocjacji do czasu aż ZSRR zobowiąże się do niewprowadzania do paktu w jakikolwiek sposób sprawy besarabskiej. Delegat rumuński kategorycznie wykluczył zredagowanie protokołu z prowadzonych negocjacji, motywując swoją postawę instrukcją otrzymaną od swego ministra oraz obowiązującym w rumuńskim MSZ od czasów protokołu moskiewskiego zakazem oficjalnych rozmów i podpisywania dokumentów, gdzie wzmiankowany byłby spór o Besarabię. Charakterystyczne, że w prywatnej rozmowie ze Stomoniakowem Sturdza uznał ten zakaz za błędny i podkreślił, iż jest jedynie wykonawcą instrukcji. W toku rozmowy dyplomata rumuński dawał do zrozumienia swojemu sowieckiemu interlokutorowi, że winowajcami zaistniałej sytuacji, w wyniku któ-

61 Protokół z 3 posiedzenia negocjacji o pakt o nieagresji między ZSRR a Rumunią z 18 I 1932, SRO, s. 356-357; protokół z 4 posiedzenia negocjacji o pakt o nieagresji między ZSRR i Rumunią z 20 I 1932, SRO, s. 360.

62 Protokół z 3 posiedzenia negocjacji o pakt o nieagresji między ZSRR a Rumunią z 18 I 1932, SRO, s. 356-357; pismo Sturdzy do Ghiki z 21 I 1932, SRO, s. 364-366; telegram Sturdzy do Ghiki z 21 I 1932, ibidem, s. 363-364; telegram Szembeka do MSZ z 22 I 1932, nr 14, HIA. Rumunia. Ks. szyf., nr 6, p. 2, f. 3; Â. M. Kopanskij, I. Ė. Levit, op. cit., s. 82-83. 
rej negocjacje kończą się przegraną zarówno Rumunii, jak i ZSRR, są polski rząd i poseł Patek, którzy wprowadzili w błąd Bukareszt odnośnie do zamiarów NKID ${ }^{63}$.

Kiedy Stomoniakow - jak sam twierdzi - poinformował Sturdzę, iż ZSRR opublikuje komunikat o „bezprzykładnym zachowaniu się” rumuńskiego rządu i jego delegata, niegodzących się na żaden oficjalny zapis kontrpropozycji sowieckiej, rumuński dyplomata zaproponował sowieckiemu negocjatorowi przesłanie pod swoim adresem oświadczenia $\mathrm{w}$ formie listu. Jego otrzymanie Rumun zamierzał potwierdzić własnym listem bez odnoszenia się do treści pisma sowieckiego. Inną wersję wydarzeń przedstawia Sturdza, który twierdzi, iż Stomoniakow, nie mając możliwości zredagowania protokołu, przesłał mu list ze swoim oświadczeniem ${ }^{64}$. Dyplomata rumuński miał zamiar od razu go odesłać, lecz nie uczynił tego pod wpływem polskiego posła RP w Rydze Mirosława Arciszewskiego, który poprosił go, aby pozostawił w ten sposób otwarte drzwi do ewentualnego wznowienia negocjacji. W rezultacie list został odesłany dwa dni później; zaczął jednak funkcjonować w sferze oficjalnej. Porównując obie wersje bliższa rzeczywistości wydaje się wersja Stomoniakowa. Tłumaczenie Sturdzy wywołuje wrażenie, iż stara się on dość pokrętnie wyjaśnić własny błąd w postaci przyjęcia listu, który był urzędowym dokumentem. W tej sytuacji było to złamanie instrukcji dotyczącej dystansowania się dyplomacji rumuńskiej od jakiejkolwiek oficjalnej wymiany zdań z Sowietami na temat sporu o Besarabię ${ }^{65}$.

Po skonstatowaniu impasu rokowań w Rydze Zaleski polecił zawiadomić Bukareszt, iż Polska zgodnie z wcześniejszymi ustaleniami odmówiła ZSRR podpisania uzgodnionego już paktu o nieagresji, wyrażając jedynie gotowość jego parafowania, co nastąpiło 25 stycznia 1932 roku. Na Wierzbowej uważano wszakże, iż pertraktacje rumuńsko-sowieckie powinny być nadal prowadzone. Stąd też w zasadzie pozytywnie przyjęto deklarację Ghiki z 20 stycznia, zapowiadającą podjęcie rozmów z Litwinowem w czasie najbliższego pobytu w lutym w Genewie, uważając jednak, iż korzystniej byłoby kontynuować pertraktacje w stolicy Łotwy. Ze zrozumieniem odniesiono się do odrzucenia przez Rumunów zaproponowanej przez Stomoniakowa formuły artykułu I, ustępu 2. Jednocześnie sugerowano, aby rząd rumuński upoważnił Sturdzę do przekazania Stomoniakowowi odpowiedzi na jego list, w którym znalazłoby się stwierdzenie, iż między Rumunią a ZSRR nie istnieje jakakolwiek „sporna kwestia terytorialna”, a celem Bukaresztu jest wprowadzenie do tekstu paktu konstatacji, iż żadna ze stron nie zamierza podejmować względem kontrahenta działań agresywnych. Skutkiem wprowadzenia tego passusu miało być usunięcie z tekstu ustępu 2 artykułu I. Rumuńskie MSZ odpowiedziało Szembekowi, iż jest gotowe wznowić rokowania ze Stomoniakowem pod warunkiem uzyskania od niego zapewnienia, że sprawa Besarabii nie zostanie w pakcie podjęta.

63 Telegram Stomoniakowa do Litwinowa z 20 I 1932, SRO, s. 360-362; zob. też D. Ghyka, op. cit., s. 307.

64 List Stomoniakowa do Sturdzy z 20 I 1932, SRO, s. 362-363, zob. też L. Pădureac, op. cit., s. 116-117.

65 Telegram Stomoniakowa do Litwinowa z 20 I 1932, SRO, s. 361-362; pismo Sturdzy do Ghiki z 21 I 1932, ibidem, s. 364-366; M. Sturdza, op. cit., s. 70. 
Nie wykluczano, iż Bukareszt mógłby podpisać pakt przy jednostronnej deklaracji sowieckiej dotyczącej Besarabii, tak jak to miało miejsce przy okazji finalizacji protokołu moskiewskiego. Podkreślano jednocześnie, iż Rumunia nie może się zgodzić na stwierdzenie, że kwestia besarabska nie jest dla niej zamknięta, bo oznaczałoby to dopuszczenie interpretacji, iż pakt nie odnosi się do całości terytorium królestwa. Bukareszteńskie MSZ skłaniało się też do rezygnacji w ustępie 2 z wyrażeń „integralność terytorialna”, „nietykalność” i „suwerenność”. W zamian proponowano przyjęcie formuły geograficznej dla określenia terytorium, która funkcjonowała w układzie podpisanym 20 listopada $1923 \mathrm{r}$. w Tyraspolu ${ }^{66}$.

Parafowanie paktu zostało przyjęte nad Dambovitą z niepokojem. Na łamach prasy rumuńskiej pisano o zerwaniu przez Warszawę jednolitego frontu stworzonego dzięki wspólnemu podpisaniu protokołu moskiewskiego, porzuceniu Rumunów, którzy „dopiero teraz zostali pobici” oraz tolerowaniu aspiracji Moskwy oparcia granicy na Prucie. W tej sytuacji wiceminister Beck nakazał posłowi RP w Bukareszcie, aby oświadczył premierowi Iordze, iż Polska „ze względu na trudności w rokowaniach" rumuńsko-sowieckich, pomimo usilnych zabiegów Litwinowa odmówiła podpisania paktu i nie wprowadzi go w życie, jeśli Bukareszt nie dojdzie do porozumienia z Moskwą. Beck polecił też Szembekowi zamieszczenie w prasie rumuńskiej oświadczenia informującego „że parafowanie paktu w Moskwie oznacza, że między Polską a Sowietami uzgodniony został tekst paktu i że rząd polski stojąc na stanowisku swoich aliansów pakt podpisze $\mathrm{z}$ chwilą, gdy podobne pakty o nieagresji między Rosją, a innymi państwami sąsiedzkimi zostaną zawarte" ${ }^{\prime 2}$.

Po parafowaniu układu o nieagresji z Polską Litwinow udzielił agencji TASS wywiadu, w którym m.in. oświadczył, iż pakt z Rumunią jest już prawie ustalony. Podkreślił, że obie strony zgodziły się na pozostawienie na boku nierozwiązanej kwestii Besarabii. Wskazał jednak, iż między państwami nieutrzymującymi ze sobą stosunków dyplomatycznych i pozostającymi „,w poważnych sporach terytorialnych i innych" niemożliwe jest zawarcie takiego paktu bez wzmiankowania o ich niezałatwieniu i pozostawieniu na boku. Zaznaczył, iż ZSRR nie zgodzi się na pominięcie w pakcie tych sporów, gdyż Rumunia mogłaby zinterpretować to jako milczącą akceptację Moskwy dla okupacji Besarabii. Nie do przyjęcia dla Związku Sowieckiego byłoby również wprowadzenie sformułowań, z których wynikałoby uznanie przezeń

66 Telegramy Zaleskiego do poselstwa w Bukareszcie z 21 I (nr 9), 22 I (nr 12- stąd cytaty) 1932, HIA. Rumunia. Ks. szyf., nr 6, p. 2, f. 3; telegramy Becka do poselstwa w Bukareszcie z 21 I (nr 11), 25 I (nr 15), 26 I (nr 16) 1932, ibidem; telegram Szembeka do MSZ z 22 I 1932, nr 14, ibidem (stąd kolejne cytaty); memoranda Ariona z 21, 22 I 1932, Behind..., s. 86-89; oświadczenie ministra Ghiki w Pradze, „Gazeta Polska” 21 I 1932, s. 2; zapis rozmowy Litwinowa z Patkiem z 23 I 1932, DVP, t. XV, s. 51-52.

67 Memoranda Ariona ze I [po 28 - stąd pierwszy cytat], [po 29] 1932, Behind..., s. 89-91; telegram Becka do poselstwa w Bukareszcie z 27 I 1932, nr 19, HIA. Rumunia. Ks. szyf., nr 6, p. 2, f. 3 (stąd pozostałe cytaty); telegram Szembeka do MSZ z 28 I 1932, nr 16, ibidem; ZSRR a zachodni sasiedzi. Stanowisko opinii rumuńskiej, „Gazeta Polska” 27 I 1932, s. 2; M. Wołos, op. cit., s. 565; T. Sandu, op. cit., s. 379; zob. też telegramy Szembeka z 30 I (nr 18), 31 I (nr 19) 1932, HIA. Rumunia. Ks. szyf., nr 6, p. 2, f. 3; Minister Zaleski o pakcie polsko-sowieckim. Wywiad specjalny udzielony agencji „Iskra”. „Gazeta Polska” 28 I 1932, s. 1; Â. M. Kopanskij, I. Ė. Levit, op. cit., s. 91. 
suwerenności Rumunii nad Besarabią lub uznanie rzeki Dniestr jako granicy Królestwa. Według Litwinowa w pakcie winno być „zupełnie wyraźnie powiedziane, że obie strony zachowują swoje stanowiska w spornej sprawie i że zawarcie paktu nie przynosi tym stanowiskom żadnego uszczerbku”. Jako ustęp 2 artykułu I szef NKID zaproponował, iż ,jako złamanie paktu będą uważane wszelkie próby rozwiązania drogą gwałtu istniejących między obu stronami terytorialnych i innych sporów"68.

Dyplomacja polska oceniła ofertę Litwinowa jako wartą rozważenia. Stąd też Szembek otrzymał polecenie czuwania, by Bukareszt jasno i konstruktywnie sformułował swe oficjalne stanowisko i nie podejmował działań, które uniemożliwiłyby podjęcie pertraktacji z Sowietami. Zapewne obawiając się storpedowania oferty przez rumuńskie MSZ, nakazano posłowi RP nawiązanie bezpośredniego kontaktu z premierem Nicolae Iorgą, który jako historyk był dodatkowo zainteresowany rewindykacją rumuńskiego skarbu narodowego i archiwaliów skonfiskowanych przez bolszewików ${ }^{69}$. Propozycja szefa NKID nie zyskała akceptacji w Palatul Sturdza. Arion w rozmowie z Szembekiem wskazywał, iż Sowiety deklarując nieotwieranie kwestii Besarabii w istocie wprowadzają wzmiankę o niej do tekstu paktu, na co jak wiadomo Rumuni nie wyrażają zgody w jakiejkolwiek formie ${ }^{70}$.

Do spotkania Szembeka z Iorgą doszło 28 stycznia. Premier uznał, iż pertraktacje ze Związkiem Sowieckim znalazły się w martwym punkcie. Należy zatem ponownie je podjąć, formułując nowe podstawy. Inicjatorem ich wznowienia mogłaby być Polska ze względu na wcześniejsze oświadczenie, że podpisanie paktu z ZSRR uzależnia od finalizacji układu rumuńsko-sowieckiego. W pakcie wg premiera miałaby się znaleźć konstatacja, iż obie strony „zobowiązują się nie załatwiać zbrojnie żadnego sporu przeszłego, obecnego, czy przyszłego”. Iorga przygotował także szkic deklaracji zabarwionej naukowymi sformułowaniami, w której wspominał o rumuńskim skarbie i archiwaliach pozostających w rękach sowieckich. W ocenie Szembeka propozycje premiera były co prawda niedopracowane, ale konstruktywne; stąd też należało je doprecyzować oraz wspierać zanim sprzeciwi się wspomnianej formule rumuńskie MSZ. Kierownictwo dyplomacji polskiej oczekiwało podjęcia szybkich działań w definiowaniu rumuńskiej oferty, gdyż zbliżały się do końca negocjacje łotewsko-sowieckie i Stomoniakow niebawem miał opuścić Rygę. Odpowiedź z Bukaresztu ujrzała światło dzienne 2 lutego. Iorga oświadczył, iż za sprawą decyzji króla Karola rokowania będą się toczyć między Ghiką a Litwinowem w Genewie, na bazie formuły wykoncypowanej przez szefa rządu. Należy podkreślić, iż ze względu

68 Wywiad Litwinowa dla TASS z 26 I 1932, DVP, t. XV, s. 57-58; raport Bilciurescu do MSZ z 27 I 1932, AMAE. 71/1920-1944 U.R.S.S. Vol. 68, k. 123-126; ZSRR a zachodni sąsiedzi. Oświadczenie kom. Litwinowa, „Gazeta Polska” 27 I 1932, s. 1; zob. też M. I. Mel'tûhov, op. cit., s. 159.

69 Aktywa rumuńskie, obejmujące m.in. zabytkowe monety, cenne rękopisy i archiwalia, zostały ewakuowane w końcu 1916 r. na terytorium Rosji po klęskach armii rumuńskiej poniesionych w wojnie z państwami centralnymi. Rząd bolszewicki skonfiskował ten majątek na początku $1918 \mathrm{r}$. Szerzej: M. Romașcanu, Tezaurul român de la Moscova, București 1934, s. 3 i n.

70 Telegram Becka do poselstwa w Bukareszcie z 27 I 1932, HIA. Rumunia. Ks. szyf., nr 6, p. 2 , f. 3; memorandum Ariona ze I [po 26] 1932, Behind..., s. 89. 
na „nieścisłość i bałamutny umysł” premiera, Szembek odniósł się sceptycznie do możliwości zastosowania tej formuły. Przewidywał, iż będzie ona zwalczana przez Palatul Sturdza, gdzie prowadzono prace nad znalezieniem formuły geograficznej (Dniestr, Morze Czarne). Poseł RP uważał, że w tej sytuacji sprawą istotną będzie „odpowiednie urobienie i przypilnowanie Ghiki” odnośnie do wznowienia rozmów z ZSRR oraz uwzględnienie $w$ tych działaniach wpływu na ministra Nicolae Titulescu - posła w Londynie i przedstawiciela Rumunii w Lidze Narodów, usposobionego bardzo niechętnie do możliwości zawarcia paktu z Moskwą ${ }^{71}$.

Titulescu od lat pełniąc wspomniane funkcje oraz będąc w okresie 1927-1928 ministrem spraw zagranicznych, zdobył znaczny autorytet na arenie międzynarodowej, co rzutowało też na jego wysokie notowania w kraju. Autorytet ten sprawił, że jeszcze w latach dwudziestych otrzymał on nieoficjalnie, jednakże ogólnie uznawane prawo do nadzorowania wszelkich rumuńskich negocjacji z obcymi państwami. Stąd też z gniewem odniósł się on do faktu niepoinformowania go przez rząd Iorgi o mających nastąpić pertraktacjach w Rydze, o których dowiedział się od swego przyjaciela ministra Zaleskiego. W telegramie do Ghiki Titulescu wyraził obawę, iż podjęcie rozmów z Sowietami może im dać okazję do publicznego zakwestionowania statusu Besarabii. Rozmowy w stolicy Łotwy w pewnym stopniu potwierdziły przewidywania posła w Londynie. Ich fiasko oraz trzymanie Titulescu przez rząd w dalszym ciągu na uboczu kwestii ewentualnych rokowań z ZSRR, dały mu pretekst do ostrej krytyki gabinetu oraz demonstracyjnego złożenia dymisji z piastowanych funkcji po powrocie w końcu lutego 1932 r. z Genewy do Bukaresztu. Ze względu na wpływy Titulescu w kraju i za granicą, król Karol II stanął po jego stronie i zmusił rząd Iorgi, by konsultował z posłem Londynie wszelkie sprawy dotyczące polityki zagranicznej Rumunii ${ }^{72}$.

Titulescu był przeciwny rozmowom Ghiki z Litwinowem w Genewie. Gdyby jednak z jakichś powodów musiało do nich dojść, należałoby je opóźnić dla spokojnego naszkicowania planu. Delegat Rumunii w Lidze Narodów podkreślał jednak, iż jeśli jest się w sytuacji „beati possidentes”, trzeba unikać czegokolwiek, co mogłoby zostać uznane jako przeszkadzające posiadaniu. W jego opinii domyślne lub jawne uznanie istnienia sporu równałoby się zgodzie Rumunii na rozstrzygnięcie „kiedys'” kwestii przynależności Besarabii ${ }^{73}$.

Stanowisko Titulescu pozostało zapewne nie bez wpływu na postawę Ghiki, który mimo instrukcji premiera Iorgi nie przejawiał chęci do podjęcia rozmów z szefem NKID, uzasadniając to zmianą nastawienia Polski i Francji. W rozmowie

71 Telegram Szembeka do MSZ z 28 I (nr 17), 2 II (nr 20) 1932, HIA. Rumunia. Ks. szyf., nr 6, p. 2, f. 3; telegram Schaetzela do poselstwa w Bukareszcie z 1 II 1932, nr 21, ibidem.

72 Telegram Titulescu do MSZ z 12 XII 1931, Behind..., s. 48-49; telegram Titulescu do MSZ z 7 VII 1932, ibidem, s. 126-127; W. M. Bacon, jr, Nicolae Titulescu şi politica externă a României 1933-1934, Iaşi 1999, s. 42; N. Iorga, O viaţă de om aşa cum a fost, [bez miejsca wydania] 2011, s. 521; zob. też memorandum Ariona z II [po 10] 1932, Behind..., s. 92-93; A. Dubicki, Nicolae Titulescu portret polityka i dyplomaty, Łomianki 2010, s. 14-20; G. Gafencu, op. cit., s. 295

73 Memorandum Ariona z II [po 10] 1932, Behind..., s. 92-93. 
przeprowadzonej z Zaleskim 11 lutego, ten jakoby stwierdził, iż Warszawa „nie ma już dzisiaj specjalnego zainteresowania w sprawie paktu”. Jej najważniejszy cel, jakim było ,jasne zadokumentowanie solidarności i wspólnego frontu” limitrofów wobec ZSRR, został bowiem osiągnięty; nie bez znaczenia było też wrażenie, jakie fakt ten wywołał w Berlinie. Szef polskiego MSZ miał jeszcze zaznaczyć, iż w tym stanowisku utwierdza go nastawienie „oficjalnych kół francuskich”, dla których pakt także „nie przedstawia już bezpośredniego interesu”. Nieco inaczej wygląda relacja Zaleskiego z przeprowadzonej rozmowy. Miał on usłyszeć od rumuńskiego ministra, że ten „stracił wszelką nadzieję na porozumienie z Rosją”, do którego sceptycznie odnosi się również Francja oraz król Karol II. W czasie rozmowy szef polskiego MSZ jakoby odniósł wrażenie, że jego rumuński kolega obawia się nacisku ze strony Polski w formie groźby podpisania przez nią osobnego układu z ZSRR. Pragnąc rozwiać te niepokoje Zaleski stwierdził, że o presji nie może być mowy, co Ghica mógł przejaskrawić i wykorzystać jako argument do niepodejmowania pertraktacji. Należy tu dodać, iż w czasie tej wymiany zdań gospodarz Wierzbowej nie artykułował potrzeby podjęcia w Genewie rozmów sowiecko-rumuńskich. Można przyjąć, iż nie zachęcało go do tego stanowisko ZSRR w kwestii rozbrojenia i wspominana już postawa Francuzów ${ }^{74}$.

W tym czasie nastawienie III Republiki wobec podpisania paktu z ZSRR było mało klarowne. Niechęć dyplomacji sowieckiej do ujawnienia w związku z Genewską Konferencją Rozbrojeniową rzeczywistej liczebności sił zbrojnych swego kraju, a następnie podawanie danych nieodpowiadających prawdzie, demagogiczne podejście do sprawy rozbrojenia, spowodowały u części polityków francuskich usztywnienie stanowiska $\mathrm{w}$ sprawie podpisania paktu. Niechętny temu był m.in. Andre Tardieu - minister wojny w gabinecie Lavala, a od 20 lutego 1932 r. premier i minister spraw zagranicznych III Republiki. Postawa ta kontrastowała z nastawieniem Berthelota, bardzo zaangażowanego w doprowadzenie do finalizacji układu. Sekretarz Generalny Quai d'Orsay czynił wręcz zachęty wobec Rumunów, aby ci podjęli negocjacje $\mathrm{z}$ Rosjanami. Tardieu natomiast stał na stanowisku, aby ZSRR zrezygnował wobec Rumunii ze stawiania jakichkolwiek warunków oraz zaproponował formułę usuwającą wszelkie możliwe przyczyny zbrojnego konfliktu $\mathrm{z}$ tym państwem ${ }^{75}$. Postawa ta nie nastrajała Rumunów do wychodzenia z inicjatywą w sprawie negocjacji i podpisania paktu z Sowietami.

74 Telegram Szembeka do MSZ z 12 II 1932, nr 22, HIA. Rumunia. Ks. szyf., nr 6, p. 2, f. 3; telegram Szembeka do Delegacji Polskiej przy Lidze Narodów z 13 II 1932, nr 2, ibidem; telegram Becka do poselstwa w Bukareszcie z 16 II 1932, nr 26, ibidem; telegram Zaleskiego z Genewy do MSZ z 17 II 1932, nr 1, ibidem.

75 Telegramy Dowgalewskiego do LKZS z 1 i 18 II 1932, DVP, t. XV, s. 73, 120; telegram Ghiki do MSZ z 22 II 1932, Behind..., s. 93; telegram Litwinowa do LKZS z 26 II 1932, DVP, t. XV, s. 140; sprawozdanie Dowgalewskiego z rozmowy z Tardieu z 4 III 1932, DVP, t. XV, s. 161; telegram Szembeka z 18 III 1932, HIA. Rumunia. Ks. szyf., nr 6, p. 2, f. 3; telegram Cesianu do MSZ z 27 III 1932, Behind..., s. 96-97; M. Wołos, op. cit., s. 554-557; T. Sandu, op. cit., s. 382-386. 
Tymczasem Wierzbowa była za szybkim rozpoczęciem działań w tej sprawie. $\mathrm{W}$ instrukcji skierowanej do posła RP w Bukareszcie, wiceminister Beck z niepokojem konstatował utknięcie jej w martwym punkcie. Wskazywał, iż w sytuacji jak mu się wydawało - bliskiego podpisania paktu estońsko-sowieckiego, wejście w życie wszystkich układów podpisanych przez zachodnich sąsiadów ZSRR jest uzależnione już tylko od postawy Rumunii. W opinii Becka dalsze przeciąganie sprawy spowoduje dojście do głosu partykularnych interesów tych państw i zagrozi rozpadem wspólnego frontu wobec Moskwy, stworzonego wcześniej przez „akcję paktową". Wiceszef polskiej dyplomacji nie dostrzegał „żadnych realnych przeszkód” stojących przed Rumunami na tej drodze. Stwierdzał, iż Bukareszt nie może się kierować niechęcią „pewnych kół” w Paryżu do podpisania paktu francusko-sowieckiego i odnosić tego do własnych negocjacji z Moskwą, gdyż III Republika nie graniczy ze ZSRR i znajduje się w zupełnie innej sytuacji niż Rumunia. Beck podkreślał konieczność solidarności limitrofów dla „moralnego rozbrojenia mas rosyjskich” oraz utrzymania na Konferencji Rozbrojeniowej klauzuli rosyjskiej. Dlatego też nakazał Szembekowi interwencję u premiera Iorgi, w celu poznania stanowiska i zamiarów rządu rumuńskiego w sprawie rokowań z Moskwą ${ }^{76}$.

Szembekowi nie udało się uzyskać precyzyjnych informacji odnośnie do stanowiska rządu rumuńskiego w sprawie rozmów z Sowietami. 17 lutego premier Iorga zakomunikował mu jedynie, iż przebywający w Genewie Ghica otrzymał polecenie zasięgnięcia rady Zaleskiego w sprawie dalszego postępowania. Szembek skonstatował wówczas negatywne nastawienie rumuńskiego ministra do sprawy rozmów z Rosjanami, upatrując w tym wpływu francuskich kół prawicowych. Poseł RP nie dostrzegł takiej postawy wśród bukareszteńskich czynników miarodajnych, które $\mathrm{w}$ jego opinii $\mathrm{w}$ dalszym ciągu uznawały potrzebę zawarcia paktu z ZSRR, przy odpowiednim zabezpieczeniu interesów rumuńskich. Niedługo potem doszło do spotkania w Genewie obu ministrów spraw zagranicznych, gdzie Ghica podtrzymał swoją dotychczasową negatywną postawę, nie wykazując najmniejszych chęci spotkania $\mathrm{z}$ Litwinowem ${ }^{77}$.

26 lutego doszło do osobistej wymiany zdań między szefem NKID a Zaleskim. Zapytany przez Litwinowa o termin podpisania przez Polskę paktu o nieagresji z ZSRR, gospodarz Wierzbowej odpowiedział, że Polska nie wprowadzi w życie paktu, jeśli wcześniej nie wejdą w życie pakty z państwami bałtyckimi i Rumunią, nawet gdyby doszło do tego $\mathrm{z}$ ich winy. Zaleski wspomniał o swoich zaleceniach dawanym Rumunom, by nie upierali się przy swoich żądaniach odnośnie do treści paktu. Wydawał się dostrzegać możliwość finalizacji paktu, pod warunkiem, że Moskwa i Bukareszt znajdą zadowalającą formułę. Równocześnie jednak wyraził

76 Telegram Becka do poselstwa w Bukareszcie z 12 II 1932, nr 24, HIA. Rumunia. Ks. szyf., nr 6, p. 2, f. 3 .

77 Telegram Szembeka do Delegacji polskiej w Genewie z 17 II 1932, HIA. Rumunia. Ks. szyf., nr 6, p. 2, f. 3; telegram Szembeka do MSZ z 18 III 1932, nr 26, ibidem; telegram Ghiki do MSZ z 22 II 1932, Behind..., s. 93. 
przypuszczenie, iż nowy francuski rząd Tardieu nie podpisze paktu ze Związkiem Sowieckim i być może będzie powstrzymywał przed tym Rumunię ${ }^{78}$.

Kilka dni później Zaleski spotkał się z Titulescu relacjonując mu treść rozmowy z Litwinowem. Polityk rumuński wskazał, iż w odniesieniu do kwestii paktu rumuńsko-sowieckiego należałoby nie tyle szukać jego formuły, ile określić podstawę rozmów. Stwierdził on, że formułę można byłoby znaleźć, gdyby kwestia Besarabii została pozostawiona „na stronie”. Jednakże oficjalnie funkcjonujący list Stomoniakowa do Sturdzy, w którym została stwierdzona bezprawność posiadania przez Rumunię Besarabii, powoduje, iż jakakolwiek formuła czyniłaby siłą rzeczy otwartą kwestię przynależności tego terytorium. W tej sytuacji jakiekolwiek pertraktacje byłyby dla Bukaresztu nie do przyjęcia. Zaleski rzekomo przyznał rację swemu interlokutorowi, wyrażając pogląd, iż zabiegi o pakt mogłyby zostać wznowione, jeśli ZSRR oficjalnie wycofałyby wzmiankowany list.

Warunki sformułowane przez Titulescu zupełnie nie przystawały do sowieckiej wizji paktu. Litwinow w wywiadzie dla „Dziennika Poznańskiego” zadeklarował gotowość podpisania paktu, który nie niósłby ze sobą rezygnacji Związku Sowieckiego z Besarabii, ani tym bardziej wzmacniał stanowisko Rumunii w tej kwestii. Pozostawiałby natomiast jako otwartą sporną kwestię terytorialną, nie przynosząc szkody żadnej ze stron i umożliwiając im trwanie przy swoich stanowiskach.

$\mathrm{W}$ tej samej rozmowie z Zaleskim dyplomata rumuński wyraził przekonanie, że pakt mógłby utrudnić realizację celów Bukaresztu na Konferencji Rozbrojeniowej, gdyż dyplomacja sowiecka mogłaby wykorzystywać jego podpisanie jako argument dla redukcji sił zbrojnych Rumunii, uzasadniając to podniesieniem bezpieczeństwa jej granicy wschodniej. Ze względu na podatność międzynarodowej opinii publicznej na demagogię i kłamstwa Sowietów, Bukareszt powinien uważnie obserwować jej nastawienie w kwestii rozbrojenia. Dokonane pod presją opinii ewentualne ustępstwa w tej sprawie byłyby wg Titulescu tym groźniejsze, że Rumunia nie posiadała uznanej granicy wschodniej ani wystarczającego budżetu wojskowego, od którego zależne były możliwości obronne armii ${ }^{79}$.

Niedługo po rozmowie obu dyplomatów pojawiły się nowe trudności na drodze do paktu o nieagresji miedzy Rumunią a Sowietami. Wykorzystując incydenty na granicy obu państw, do których doszło za sprawą ZSRR, premier Iorga oświadczył, iż jego rząd wyczerpał już wszelkie możliwości porozumienia z Moskwą. Podkreślił też, iż Rumunia nie ponosi odpowiedzialności za ciągłe wysuwanie przez NKID sprawy Besarabii, co sprawia, że zawarcie paktu nie może dojść do skutku. W oce-

78 Telegram Litwinowa do LKSZ z 26 II 1932, DVP, t. XV, s. 140-141; telegram Titulescu do MSZ z 2 III 1932, Behind..., s. 94-95; fragment pisma Stomoniakowa do Antonowa-Owsiejenki z 5 III 1932, DMHSPR, t. V, s. 588-589; Â. M. Kopanskij, I. Ė. Levit, op. cit., s. 94.

79 Telegram Zaleskiego do poselstwa w Bukareszcie z 2 III 1932, nr 2, HIA. Rumunia. Ks. szyf., nr 6, p. 2, f. 3; telegramy Titulescu do MSZ z 2, 9 III 1932, Behind..., s. 94-96; telegram Massigliego do Berthelota z 10 III 1932, La Grande Roumanie alliée de la France. Une péripétie diplomatique des Années Folles? (1919-1933), oprac. T. Sandu, Montréal 1999, s. 225-226; M. Wojdyłło, Sowiety nie wierzą w pomyślny przebieg obrad genewskich, „Dziennik Poznański”, 6 III 1932, s. 1. 
nie zastępującego Szembeka radcy Kobylańskiego, rząd bukareszteński pragnął się w ten sposób zdystansować od ewentualnych negocjacji z ZSRR, zrzucając na to państwo „odium odpowiedzialności”. Niedługo potem, być może pod wpływem Szembeka, Rumuni wycofali się z tego kategorycznego stanowiska. Sprawy podjęcia negocjacji z ZSRR nie posunęło to jednak naprzód, ponieważ Ghica odżegnywał się od wystąpienia $\mathrm{z}$ inicjatywą w tej sprawie. Spodziewał się podjęcia jej przez Polskę lub Francję i gotów był przystąpić wówczas, gdy Związek Sowiecki zrezygnuje $\mathrm{z}$ wprowadzenia do paktu wzmianki o Besarabii. W stanowisku odsuwania negocjacji utwierdzał Rumunów Tardieu, który stwierdził, iż po zbadaniu tekstu układu rumuńsko-sowieckiego uważa go za nieodpowiedni i wymagający zrewidowania, czym jednak będzie mógł się zająć najwcześniej w czerwcu, czyli po wyborach parlamentarnych we Francji ${ }^{80}$. Sprawa paktu rumuńsko-sowieckiego znalazła się w impasie.

Rumuni od początku pojawienia się inicjatywy zawarcia paktu o nieagresji z ZSRR nie widzieli dla siebie w związku z nim większych korzyści. Niepokoili się, iż rozmowy o pakcie wyciągną na światło dzienne sprawę Besarabii, której przynależność do Rumunii nie miała sankcji międzynarodowej ani uznania Związku Sowieckiego. Obawiali się również, iż podpisanie paktu w konsekwencji przyniesie nawiązanie dyplomatycznych stosunków rumuńsko-sowieckich i otworzy tym samym Królestwo na wpływy komunistyczne, co przy ostrych problemach społecznych będących udziałem Rumunii mogło poważnie zdestabilizować jej sytuację wewnętrzną. Argument dyplomacji polskiej zbudowania wobec Związku Sowieckiego wspólnego bloku limitrofów, połączonych zawieranymi z tym państwem paktami o nieagresji, nie miał dostatecznej siły przekonywania. Zgodę Bukaresztu wymusiła dopiero presja Francji i Polski poparta uzyskaniem od Moskwy obietnicy, iż sprawa Besarabii nie będzie podejmowana w rokowaniach. Ujawniona w Rydze chęć sowieckiego negocjatora wprowadzenia do tekstu w ogólnej formule kwestii besarabskiej oraz dążenie jego rumuńskiego odpowiednika do uzyskania od ZSRR gwarancji integralności terytorialnej Rumunii spowodowały fiasko pertraktacji. Dyplomacja polska usiłowała doprowadzić do zbliżenia stanowisk obu państw. Jednak bezkompromisowe wymagania stawiane paktowi przez Titulescu oraz krytyczne nastawienie do tego układu premiera Tardieu spowodowały całkowity zastój w tej sprawie. W tych okolicznościach na Wierzbowej obawiano się, iż próba stworzenia pod auspicjami Polski wspólnego frontu sąsiadów ZSRR może zakończyć się niepowodzeniem, tym bardziej że Moskwa podejmowała już działania wobec państw bałtyckich zmierzające do storpedowania koordynacji zawierania paktów o nieagresji przez jej zachodnich sąsiadów. Przed dyplomacją polską stanęła kwestia albo rezygnacji z tej koncepcji, albo podjęcia bardziej zdecydowanych kroków wobec sojusznika rumuńskiego.

80 Telegram Kobylańskiego do MSZ z 28 III 1932, HIA, Rumunia. Ks. szyf., nr 6, p. 2, f. 3; telegram Szembeka do MSZ z 7 IV 1932, ibidem; telegram Szembeka do poselstwa w Paryżu z 8 IV 1932, ibidem; telegram Ghiki do poselstwa w Paryżu z IV 1932, AMAE. 71/1920-1944, U.R.S.S. Vol. 68, k. 137. 


\section{Poland and the Romanian-Soviet non-aggression pact issue of 1931-1932}

Summary: New tendencies had appeared in the European system of international relations in the early 1930s. German foreign policies became increasingly influenced by extreme nationalism, revisionism and anti-communism. This transition raised growing concern in Moscow, which began to doubt the sustainability of cooperation between the two countries established by the Treaty of Rapallo (1922). France seemed the only viable alternative for the USSR in case of any failure in their relations with Berlin; especially that France was also disturbed by the recent Reich's policy changes and showed interest in cooperation with the Soviet Union.

From the Polish point of view, these signs of change in the European political landscape were favourable, as they hinted the Western powers' abandonment of their course of cooperation with the Germans, which had often been implemented at the expense of the Polish national interest. This also implied the deterioration in Soviet-German cooperation, which previously excluded Poland from reaching an agreement with either the USSR or Germany. Under such circumstances, the authorities in Warsaw observed attentively the warming of French-Soviet relations, confirmed by France's proposal of a non-aggression pact in April 1931. As soon as the French side informed them on their initiative, the Polish Ministry of Foreign Affairs decided to resume its negotiations regarding a similar non-aggression pact with Moscow, which previously broke down in 1927. Poland sought to coordinate its own negotiations with those of the USSR's other western neighbours-namely Finland, Estonia, Latvia and Romania-over similar pacts.

The Romanians, who were Polish allies, remained sceptical about their own benefits from signing a non-aggression pact with the USSR ever since the emergence of that idea. They feared that the negotiations would evoke the question of Bessarabia, a region which underwent a controversial unification process with Romania that remained unapproved by the international community and unrecognised by the USSR. They also worried that the pact would result in the establishment of diplomatic relations between the two countries, thus opening the Kingdom of Romania to communist influence, which, in the light of the acute social troubles it raises, could strongly destabilise the internal situation in the country. The Polish diplomacy's plan to form a common block of USSR's western neighbours, tied by their respective pacts with the Soviet state, proved insufficiently persuasive. Bucharest's consent was eventually obtained through joint pressure of France and Poland, backed by Moscow's promise of not taking the matter of Bessarabia into consideration during negotiations. However, the USSR's desire to introduce the Bessarabian issue in the pact's content, disclosed in the course of Romanian-Soviet negotiations in Riga (January 1932), as well as Bucharest's desire to obtain a guarantee from Moscow regarding their territorial integrity, led to a breakdown in the negotiations. Polish diplomacy attempted to bring both sides closer, yet the uncompromised demands made by the influential Romanian diplomat Nicolae Titulescu, as well as the critical attitude of French Prime Minister André Tardieu towards the whole initiative resulted in a total standstill. Under such circumstances, the authorities in Warsaw feared that their attempt to create a common block of Soviet Union's neighbours under the auspices of Poland may fail, especially that Moscow had already taken some action against the Baltic states in order to sabotage the coordination of the signing of non-aggression pacts. Polish diplomacy found itself faced with the decision to either abandon the whole concept, or take more decisive action in regard to their Romanian ally.

Translated by Jakub Perliński

Польша и вопрос румынско-советского пакта о ненападении в 1931-1932 гг.

В начале 30-х гг. в европейской системе международных отношений возникли новые тенденции. Во внешней политике Германии все сильнее стали проявляться крайний 
национализм, ревизионизм и антикоммунизм. Последний из них порождал все большее беспокойство Советского Союза, который стал опасаться за прочность взаимодействия обоих государств, датировавшегося Рапалльским договором (1922 г.). Альтернативой для Москвы в случае срыва сотрудничества с Берлином оставалась, в принципе, лишь Франция, которая также была взволнована изменениями в политике Рейха и казалась заинтересованной в сотрудничестве с СССР.

Появление признаков перемен в европейском политическом порядке было, с польской точки зрения, положительным явлением. Подвергалось ослаблению нежелательное для Польши направление сотрудничества западных держав с Германией, которое осуществлялось частично за счет ее интересов; также прогрессировало разложение германо-советского взаимодействия, до сих пор исключавшего возможность соглашения как между Польшей и Советским Союзом так и Германией. В этих обстоятельствах в Варшаве с вниманием следили за потеплением франко-советских отношений, которого проявлением в апреле 1931 г. была инициатива Парижа по отношению к СССР о заключении пакта о ненападении. Французы проинформировали об этом начинании польское Министерство Иностранных Дел, которое решилось возобновить, прерванные в 1927 г., переговоры с Москвой о похожем пакте о ненападении. Их пытались координировать с переговорами об аналогичных пактах, которые с Советским Союзом велись его другими западными соседями те. Финляндией, Эстонией, Латвией и Румынией.

Румыны, будучи союзниками Польши, как только появилась инициатива по заключению пакта о ненападении с СССР, не нашли в нем для себя какой-либо большей пользы. Они беспокоились, что переговоры о пакте вытащат на свет вопрос о Бессарабии, которой принадлежность к Румынии не была ни санкционирована международным сообществом, ни признана Советским Союзом. Они также опасались, что заключение пакта принесет, в результате, установление румыно-советских дипломатических отношений и тем самым откроет Королевство Румыния для коммунистических влияний, что при острых социальных проблемах, которые выпали на его долю, могло серьезно дестабилизировать внутреннюю обстановку. Аргумент польской дипломатии, которая предлагала построить по отношению к Советскому Союзу общий блок западных соседей, объединенных, заключаемыми с этим государством пактами о ненападении, не имел достаточной силы убеждения. Согласия Бухареста добились только благодаря давлению Франции и Польши, поддержанному обещанием, полученным от Москвы, что вопрос Бессарабии не будет подниматься в переговорах. Желание СССР ввести в текст пакта бессарабский вопрос, изъявленное в ходе румыно-советских переговоров в Риге (январь 1932 г.), а также стремление Румынии получить от Москвы гарантии территориальной интегральности Королевства стали причинами разрыва переговоров.

Польская дипломатия пыталась привести к сближению позиций обоих государств. Однако бескомпромиссные требования к пакту влиятельного румынского дипломата - Николае Титулеску, а также критическое отношение к этому договору французского премьер-министра Андре Тардьё, привели к полному застою в этом деле. В этих обстоятельствах в Варшаве опасались, что попытка создания под эгидой Польши общего фронта соседей СССР может завершиться неудачей, тем более, что Москва уже предпринимала действия по отношению к прибалтийским государствам, направленные на торпедирование координации заключения пактов о ненападении ее западными соседями. Перед польской дипломатией встал вопрос или отказаться от этой концепции или предпринять более решительные шаги по отношению к румынскому союзнику.

Перевод Агнешка Поспишьль 


\section{Bibliografia}

Anghel F., Mareşalul Piłsudski în „peţit la Bucureşti”, „Magazin Istoric”, 1997, nr 9.

Bacon W. M., jr, Nicolae Titulescu şi politica externă a României 1933-1934, Iaşi 1999.

Behind closed doors. Secret papers on the failure of Romanian-Soviet negotiations 1931-1932, tłum. i wstęp W. M. Bacon, Stanford 1979.

Bułhak H., Polska-Francja. Z dziejów sojuszu 1922-1939, cz. I (1922-1932), Warszawa 1993.

Bułhak H., Polska a Rumunia 1918-1939, [w:] Przyjaźnie i antagonizmy. Stosunki Polski z państwami sasiednimi w latach 1918-1939, red. J. Żarnowski, Warszawa 1977.

Dessberg F., Le triangle impossible. Les relations franco-soviétiques et le facteur polonais dans les questions de sécurité en Europe (1924-1935), Bruxelles 2009.

Dessberg F., La Roumanie et la Pologne dans la politique soviétique de la France. La difficulté détablir un «front uni» (1924-1935), „Revue Historique des Armées”, 2006, nr 3 (244).

Dubicki A., Nicolae Titulescu - portret polityka i dyplomaty, Łomianki 2010.

Gafencu G., Insemnări politice 1929-1939, oprac. i posłowie S. Neagoe, Bucureşti 1991.

Ghyka D., Memorii (1894-1940), Iași 2004.

Gmurczyk-Wrońska M., Negocjacje polsko-sowieckie o pakt o nieagresji w roku 1927 i w latach 1931-1932, „Dzieje Najnowsze”, 2012, nr 3.

Gmurczyk-Wrońska M., Stanisław Patek w dyplomacji i polityce (1914-1939), Warszawa 2013.

Gregorowicz S., Polsko-radzieckie stosunki polityczne w latach 1932-1935, Wrocław-Łódź 1982.

Gregorowicz S., Zacharias, M. J., Polska - Związek Sowiecki: stosunki polityczne w latach 19251939, Warszawa 1995.

Hrenciuc D., România şi Polonia 1932-1939. Relaţii politice şi diplomatice, Iaşi 2005.

Iorga N., Memorii. Încercarea guvernării peste partide (1931-2), vol. VI, București 1939.

Iorga N., O viaţă de om aşa cum a fost, [bez miejsca wydania] 2011.

Jędrzejewicz W., Cisek J., Kalendarium życia Józefa Piłsudskiego 1867-1935, t. 3, 1926-1935, Wrocław 1994.

Ken O., Moskva i pakt nenapadeniâ s Pol'šej (1930-1932), Sankt Petersburg 2003.

Ken O., Rupasov A. I., Politbûro CK VKP(b) i otnošeniâ SSSR s zapadnymi sosednimi gosudarstvami (konec 1920-1930-h gg.): Problemy. Dokumenty. Opyt kommentariâ, Čast' 1: 1928-1934, Sankt Petersburg 2000.

Kopanskij Â. M., Levit I. Ė., Sovetsko-rumynskie otnošeniâ 1929-1934 gg. (ot podpisania Moskovskogo protokola do ustanovleniâ diplomatičeskih otnošenij), Moskva 1971.

Krzak A., Kontrwywiad wojskowy II Rzeczpospolitej przeciwko radzieckim służbom specjalnym 1921-1939, Toruń 2007.

La Grande Roumanie alliée de la France. Une péripétie diplomatique des Années Folles? (1919-1933), oprac. T. Sandu, Montréal 1999.

Laroche J., Polska lat 1926-1935. Wspomnienia ambasadora francuskiego, przekład i opracowanie S. Zabiełło, Warszawa 1966.

Leczyk M., Polityka II Rzeczypospolitej wobec ZSRR w latach 1925-1934. Studium z historii dyplomacji, Warszawa 1976.

Leczyk M., We francusko-polsko-rosyjskim trójkącie (1922-1934), „Dzieje Najnowsze”, 1999, nr 3.

Lepecki M., Pamiętnik adiutanta Marszałka Piłsudskiego, oprac. nauk. i przedm. A. Garlicki, Warszawa 1987.

Łopatniuk S., Polsko-radzieckie rokowania w sprawie zawarcia paktu o nieagresji (1925-1932), „Z dziejów stosunków polsko-radzieckich”, 1965, t. I.

Materski W., Na widecie. II Rzeczpospolita wobec Sowietów 1918-1943.

Mel'tûhov M. I., Bessarabskij vopros meždu mirovymi vojnami 1917-1940, Moskva 2010.

Michowicz W., Genewska Konferencja Rozbrojeniowa 1932-1937 a dyplomacja polska, Łódź 1989.

Pădureac L., Relaţiile româno-sovietice 1917-1934, Chişinău 2003. 
Patek S., Raporty i korespondencja z Moskwy (1927-1932), wstęp, wybór i oprac. M. GmurczykWrońska, Warszawa 2010.

Pepłoński A., Kontrwywiad II Rzeczypospolitej, Warszawa 2002.

Polskie Dokumenty Dyplomatyczne 1931, red. M. Wołos, Warszawa 2008.

Romașcanu M., Tezaurul român de la Moscova, București 1934.

Sandu T., Système de sécurité français en Europe centre-orientale. Lexemple roumain 1919-1933, Paris-Montréal 1999.

Schramm T., Niemcy w polityce Francji, [w:] Niemcy w polityce międzynarodowej 1919-1939, t. 2: Lata wielkiego kryzysu gospodarczego, red. S. Sierpowski, Poznań 1992.

Sierpowski S., Przemiany w polityce międzynarodowej w latach wielkiego kryzysu gospodarczego 1929-1933/35, [w:] Niemcy w polityce międzynarodowej 1919-1939, t. 2: Lata wielkiego kryzysu gospodarczego, red. S. Sierpowski, Poznań 1992.

Skrzypek A., Nie spetniony sojusz ? Stosunki sowiecko-niemieckie 1917-1941, Warszawa 1992

Skrzypek A., Niemcy w polityce ZSRR 1929-1935, [w:] Niemcy w polityce międzynarodowej 19191939, t. 2: Lata wielkiego kryzysu gospodarczego, red. S. Sierpowski, Poznań 1992.

Skrzypek A., Polsko-radziecki pakt o nieagresji z 1932 r., ZDSPR 1976, t. XIII.

Ševâkov A., Sovetsko-rumynskie otnošeniâ i problema evropejskoj bezopasnosti, 1932-1939, Moskva 1977.

Sovetsko-rumynskie otnošeniâ. Dokumenty i materialy 1917-1934, t. 1, red. A. A. Avdeev i in., Moskva 2000.

Stosunki polsko-rumuńskie w XX wieku. Wybrane zagadnienia, red. M. Patelski, M. Białokur, Toruń-Opole 2010.

Sturdza M., România şi sfârşitul Europei. Amintiri din ţara pierdută, Bucureşti 2004.

Walczak H., Sojusz z Rumunia w polskiej polityce zagranicznej w latach 1918-1931, Szczecin 2008. Wandycz P. S., The Twilight of French Eastern Alliances 1926-1936: French-Czechoslovak-Polish Relations from Locarno to the Remilitarization of the Rhineland, Princeton 1988.

Wojdyłł M., Sowiety nie wierza w pomyślny przebieg obrad genewskich, „Dziennik Poznański”, 6 III 1932.

Wołos M., Francja-ZSRR. Stosunki polityczne w latach 1924-1932, Toruń 2004.

Zacharias M. J., Polska wobec zmian w układzie sił politycznych w Europie w latach 1932-1936, Wrocław-Łódź 1981.

Henryk Walczak - doktor habilitowany, profesor Uniwersytetu Szczecińskiego, specjalizuje się w badaniach dotyczących stosunków polsko-rumuńskich w okresie międzywojennym, biografistyce i edycji źródeł. Autor monografii Sojusz z Rumuniq w polskiej polityce zagranicznej w latach 1918-1931, Szczecin 2008; współredaktor i współautor opracowania Od Moraczewskiego do Składkowskiego. Gabinety Polski Odrodzonej 1918-1939, Szczecin 2010, współredaktor Dziennika Juliusza Zdanowskiego, t. I-II, Szczecin 2013. 